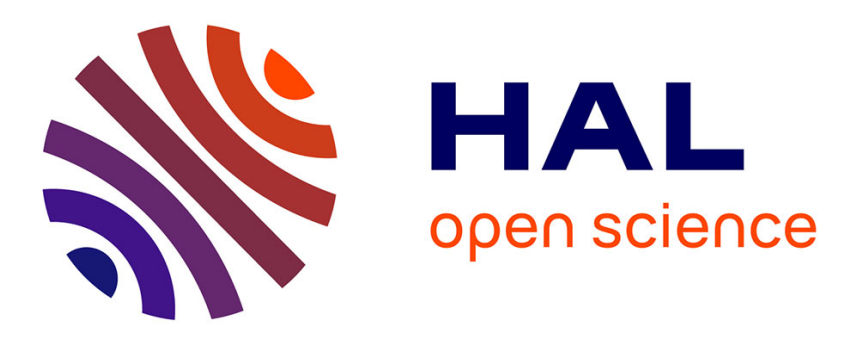

\title{
Carbon dioxide in silicate melts at upper mantle conditions: Insights from atomistic simulations
}

Rodolphe Vuilleumier, Ari P. Seitsonen, Nicolas Sator, Bertrand Guillot

\section{To cite this version:}

Rodolphe Vuilleumier, Ari P. Seitsonen, Nicolas Sator, Bertrand Guillot. Carbon dioxide in silicate melts at upper mantle conditions: Insights from atomistic simulations. Chemical Geology, 2015, 418, pp.77-88. 10.1016/j.chemgeo.2015.02.027 . hal-01130246

\section{HAL Id: hal-01130246 \\ https://hal.sorbonne-universite.fr/hal-01130246}

Submitted on 11 Mar 2015

HAL is a multi-disciplinary open access archive for the deposit and dissemination of scientific research documents, whether they are published or not. The documents may come from teaching and research institutions in France or abroad, or from public or private research centers.
L'archive ouverte pluridisciplinaire HAL, est destinée au dépôt et à la diffusion de documents scientifiques de niveau recherche, publiés ou non, émanant des établissements d'enseignement et de recherche français ou étrangers, des laboratoires publics ou privés. 


\title{
Carbon dioxide in silicate melts at upper mantle conditions: Insights from
} atomistic simulations

\author{
Rodolphe Vuilleumier ${ }^{1}$, Ari P Seitsonen ${ }^{1,2}$, Nicolas Sator ${ }^{3,4}$, and Bertrand Guillot ${ }^{3,4}$ \\ ${ }^{1}$ Laboratoire PASTEUR, UMR 8640 ENS-CNRS-UPMC Paris 6, Département de Chimie, Ecole Normale \\ Supérieure, F-75005, Paris, France \\ 2 Physikalisch-Chemiches Institut, Universität Zürich, CH-8057 Zürich, Switzerland \\ ${ }^{3}$ Sorbonne Universités, UPMC Univ Paris 06, UMR 7600, LPTMC, F 75005, Paris, France, \\ ${ }^{4}$ CNRS, UMR 7600, LPTMC, F 75005, Paris, France
}

\begin{abstract}
The detail of the incorporation of carbon dioxide in silicate melts at upper mantle conditions is still badly known. To give some theoretical guidance, we have performed first-principle molecular dynamics simulations (FPMD) to quantify the speciation and the incorporation of carbon dioxide in two $\mathrm{CO}_{2}$-rich silicate melts $\left(20 \mathrm{wt} \% \mathrm{CO}_{2}\right.$ at $2073 \mathrm{~K}$ and $\left.12 \mathrm{GPa}\right)$, a basaltic and a kimberlitic composition chosen in the $\mathrm{CaO}-\mathrm{MgO}-\mathrm{Al}_{2} \mathrm{O}_{3}-\mathrm{SiO}_{2}$ system. In the basaltic composition, carbon dioxide is incorporated under the form of a minority population of $\mathrm{CO}_{2}$ molecules and a prevailing population of carbonate ions $\left(\mathrm{CO}_{3}{ }^{2-}\right)$. In contrast, the amount of $\mathrm{CO}_{2}$ molecules is found to be very small in the kimberlitic melt. Moreover, a new (transient) species has been identified, the pyrocarbonate ion $\mathrm{C}_{2} \mathrm{O}_{5}{ }^{2-}$ issued from the reaction between $\mathrm{CO}_{2}$ and $\mathrm{CO}_{3}{ }^{2-}$. With regard to the structure of the $\mathrm{CO}_{2}$-bearing melts, it is shown that the carbonate ions modify the silicate network by transforming some of the oxygen atoms into bridging carbonates, non-bridging carbonates, and free carbonates, with a distribution depending on the melt composition. In the basaltic melt a majority of carbonate ions are non-bridging or free, whereas in the kimberlitic melt, most of the carbonate ions are under the form of free carbonates linked to alkaline earth cations. Surprisingly, the addition of $\mathrm{CO}_{2}$ only has a weak influence on the diffusion coefficients of the elements of the melt. The consequence is that the strong enhancement of the electrical conductivity reported recently for carbonated basalts (Sifré et al., 2014, Nature 509,81), can be reproduced by simulation only if one assumes that the ionic charges assigned to the elements of the melt depend, in a non-trivial way, on the $\mathrm{CO}_{2}$ content. Finally, a comparison of the FPMD calculations with classical molecular dynamics simulations using an empirical force field of the literature (Guillot and Sator, 2011, GCA 75, 1829) shows that the latter one needs some improvement.
\end{abstract}

Keywords: $\mathrm{CO}_{2}$, First-principle and classical molecular dynamics simulations, speciation, liquid structure, self-diffusion coefficients, electrical conductivity, basalt, kimberlite. 


\section{INTRODUCTION}

Evidence of $\mathrm{CO}_{2}$-rich magmas in the upper mantle are well documented. For instance, the observation of extended volcanoclastic deposits at some ocean spreading centers suggests that an explosive subaqueous volcanism with magma disruption can be driven by $\mathrm{CO}_{2}$-rich melts (Hékinian et al., 2000; Pineau et al., 2004; Sohn et al., 2008; Helo et al., 2011). Another example is given by kimberlite magmas which are volatile rich $\left(\mathrm{CO}_{2}+\mathrm{H}_{2} \mathrm{O}\right)$ and ascend from deep in the mantle at high velocity, causing violent eruptions (Sparks et al., 2006; Brooker et al., 2011; Russell et al., 2012). Related to kimberlites, the carbonatites, although volumetrically insignificant on Earth, have seen their importance recently reevaluated (Woolley and Church, 2005; Woolley and Kjarsgaard, 2008). Carbonatites are found on all continents and a world distribution map shows that carbonatitic magmatism of explosive style is abundant from the late Archean to the Phanerozoic (Bailey and Kearns, 2012; Humphreys et al., 2012), their primary melts being formed from incipient melting of subducted oceanic crust in the mantle transition zone (Walter et al., 2008) or from the partial melting of plume material when they are associated with large igneous provinces (Ernst and Bell, 2010; Bell and Simonetti, 2010; Woolley and Bailey, 2012). Furthermore, magnetotelluric sounding reveals the presence of highly conductive phases in the asthenosphere (Lizzaralde et al., 1995; Baba et al., 2006, 2010) which could be carbonatitic melts (Gaillard et al. 2008, Yoshino et al., 2012; Dasgupta et al., 2013). Thus $\mathrm{CO}_{2}$-rich melts seems to play a key role in the upper mantle for explaining the mobilization and the transport of $\mathrm{CO}_{2}$ from a source region to the surface. However, in spite of a growing interest the physicochemical properties of $\mathrm{CO}_{2}$-bearing silicate melts at mantle conditions are still poorly known.

During the last three decades many studies have been devoted to measuring the solubility of $\mathrm{CO}_{2}$ in silicate melts of various compositions. But due to experimental difficulties these studies were generally restricted to low and moderate pressures (below $~ 2$ GPa). IR spectroscopy studies (Mysen, 1976; Fine and Stolper, 1985, 1985/1986; Stolper et al., 1987; Fogel and Rutherford, 1990; Pan et al., 1991; Brooker et al., 1999, 2001a,b; Morizet et al., 2002) have emphasized the importance of $\mathrm{CO}_{2}$ 
speciation which may exist either as molecular $\mathrm{CO}_{2}$ or as carbonate ion $\left(\mathrm{CO}_{3}^{2-}\right)$, the molecular form being favored in polymerized (silicic) melts while the carbonate ion is dominant in depolymerized (basic and ultrabasic) melts. However, it has been suggested (Morizet et al., 2001; Nowak et al., 2003; Spickenbom et al., 2010; Konschak and Keppler, 2014) that the $\mathrm{CO}_{2}$ speciation observed in quenched glasses by IR spectroscopy may not be representative of that in silicate melts equilibrated at high temperature: in particular, the abundance of molecular $\mathrm{CO}_{2}$ could be underestimated in the liquid at magmatic temperatures.

Recently, in introducing an empirical force field to describe the chemical reactivity of $\mathrm{CO}_{2}$ in silicate liquids $\left(\mathrm{CO}_{2}+\left(\mathrm{O}^{2-}\right)_{\text {melt }} \leftrightarrow \mathrm{CO}_{3}^{2-}\right)$, it has been possible to evaluate by classical molecular dynamics (MD) simulation the solubility and speciation of $\mathrm{CO}_{2}$ in silicate melts in various compositions (Guillot and Sator, 2011). The conclusions of these MD calculations are twofold: (i) The solubility of $\mathrm{CO}_{2}$ increases markedly with the pressure and reaches value as high as $~ 20 \mathrm{wt} \%$ in basaltic melts at $8 \mathrm{GPa}$, and (ii) the proportion of molecular $\mathrm{CO}_{2}$ is found to be significant in $\mathrm{CO}_{2}$-saturated basic and ultrabasic melts at superliquidus temperature and high pressures, a result at variance with post mortem analyses of basaltic glasses where only carbonate ions are detected. To check the consistency of the above MD calculations and to get some new insights we have performed first-principle molecular dynamics simulations (FPMD) of $\mathrm{CO}_{2}$-rich basaltic and kimberlitic melts. The results of these FPMD simulations based on the explicit evaluation of the electronic structure are presented here. In particular, the effect of $\mathrm{CO}_{2}$ on the structure, the diffusion of elements, and the electrical conductivity of basaltic and kimberlitic melts has been evaluated.

\section{COMPUTATIONAL DETAILS}

The core of a classical MD calculation consists of solving iteratively the equations of motion of an assembly of atoms interacting via a force field. The latter one can be empirical (i.e. adjusted so as to reproduce some properties of the real material) or is obtained from a fit of a potential energy surface deduced from a quantum chemical calculation of a small part of the system under consideration (e.g. a monomer or a cluster of atoms). A more rigorous method, named FPMD, relies on the implementation of a 
molecular dynamics schema within an electronic structure calculation performed in the framework of the density functional theory (DFT). However, the computational cost of this method is very high and restricts its use to relatively small system sizes (a few hundred of atoms instead of several thousand or more with classical MD simulations) and short trajectories (10 100 ps instead of $\sim 10 \mathrm{~ns}$ with classical MD).

In the present case, the FPMD simulations were performed within the DFT framework and the BornOppenheimer approximation using the freely available program package QUICKSTEP/CP2K (VandeVondele et al., 2005a). QUICKSTEP uses a hybrid Gaussian plane-wave (GPW) method (Lippert et al. 1997). We employed a triple-zeta valence doubly polarized (TZV2P) basis set for oxygen and carbon (VandeVondele et al. 2005b). For Ca, we used the double-zeta valence plus polarization (DZVP) basis set optimized for molecules (VandeVondele et al., 2007). Core electrons were replaced by the GoedeckerTeter-Hutter (GTH) norm-conserving pseudo-potentials (Goedecker et al., 1996; Hartwigsen et al., 1998; Krack, 2005). The cutoff for the electronic density was set to $700 \mathrm{Ry}$ and the gradient corrected exchangecorrelation functional BLYP (Becke, 1998; Lee et al., 1998) was used in the DFT calculations. van der Waals interactions were taken into account using the schema DFT-D2 (Grimme, 2006). Constant temperature conditions were imposed by a Nosé-Hoover thermostat chain (Nosé, 1984a, b). The time step in the FPMD simulations was $0.5 \mathrm{fs}$, and the simulations were run for $\sim 22 \mathrm{ps}$. The simulation cell was periodically replicated in three dimensions and contained 640 atoms for describing the $\mathrm{CO}_{2}$-bearing silicate melts and about 460-470 atoms for the $\mathrm{CO}_{2}$-free melts (see Table 1 for the investigated chemical compositions and the discussion below).

The results of FPMD simulations were compared to those generated by classical MD simulations and based upon the empirical force field developed by Guillot and Sator (2011) for the multi component system $\left(\mathrm{CO}_{2}-\mathrm{SiO}_{2}-\mathrm{TiO}_{2}-\mathrm{Al}_{2} \mathrm{O}_{3}-\mathrm{Fe}_{2} \mathrm{O}_{3}-\mathrm{FeO}-\mathrm{MgO}-\mathrm{CaO}-\mathrm{Na}_{2} \mathrm{O}-\mathrm{K}_{2} \mathrm{O}\right)$. This force field (see Table 1 in Guillot and Sator, 2011) allows one to deal with the chemical reaction, $\mathrm{CO}_{2}+\left(\mathrm{O}^{2-}\right)_{\text {melt }} \leftrightarrow \mathrm{CO}_{3}^{2-}$, where a $\mathrm{CO}_{2}$ molecule reacts with an oxygen atom of the silicate melt to produce a carbonate ion (and vice versa). It was implemented into the DL_POLY 2.0 code for MD simulations (Smith and Forrester, 1996) in which the equations of motions for atoms were solved with the Verlet algorithm with a time step of $1 \mathrm{fs}$. The simulation box, composed of the same number of atoms as in FPMD calculations (see Table 1), was replicated in $3 \mathrm{D}$ and the long range coulombic interactions were evaluated by a Ewald sum. MD 
calculations were performed in the microcanonical ensemble (NVE) for evaluating dynamical properties, and in the canonical ensemble (NVT), or in the isothermal-isobaric ensemble (NPT), for determining the thermodynamic properties. The cost in computer time being much smaller than for FPMD calculations long simulation runs were performed for a better statistics (up to $10,000 \mathrm{ps}$ or $10 \mathrm{~ns}$ ).

Silicate melts from the $\mathrm{CaO}-\mathrm{MgO}-\mathrm{Al}_{2} \mathrm{O}_{3}-\mathrm{SiO}_{2}$ (CMAS) system were chosen for our simulations because they have been used since long as realistic models for investigating the properties of natural magmas over a large composition range (Scarfe et al., 1983; Rivers and Carmichael, 1987; Rigden et al., 1988; Courtial and Dingwell, 1999; Shaw, 2004; Ai and Lange, 2008). Moreover, as these melts are ironfree their investigation avoids to deal with the iron redox, a difficult task when using FPMD calculations. The role of $\mathrm{CO}_{2}$ on deep melting in the upper mantle has been enlightened thanks to partial melting

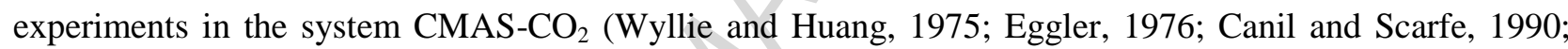
Dalton and Presnall, 1998; Gudfinnsson and Presnall, 2005; Keshav and Gudfinnsson, 2010; Keshav et al., 2011). Gundfinnsson and Presnall (2005) have shown that the partial melting at 3-8 GPa of a silicatecarbonate phase assemblage involving garnet lherzolite in equilibrium with $\mathrm{CO}_{2}$-bearing melts yields a continuous gradation in melt composition with temperature from carbonatitic to kimberlitic and basaltic. For instance at $7.6 \mathrm{GPa}$ and $1973 \mathrm{~K}$ the melt in coexistence has a kimberlitic composition $\left(35.8 \mathrm{wt} . \% \mathrm{SiO}_{2}\right.$, 2.8 wt. $\% \mathrm{Al}_{2} \mathrm{O}_{3}, 36.6$ wt. $\% \mathrm{MgO}$ and 24.8 wt. $\% \mathrm{CaO}$ in a $\mathrm{CO}_{2}$-free basis) with 20.6 wt. $\% \mathrm{CO}_{2}$. We have chosen to investigate by FPMD simulation this kimberlitic composition with 20.6 wt. $\% \mathrm{CO}_{2}$, but at a slightly higher temperature $(2073 \mathrm{~K})$. Notice that the melt is likely undersaturated in $\mathrm{CO}_{2}$ at the investigated thermodynamic conditions because there is no evidence of a vapor phase in the experimental data of Gudfinnsson and Presnall (2005). Furthermore, the evaluation by classical MD simulation of the solubility of $\mathrm{CO}_{2}$ in this kimberlitic melt, in using the procedure of Guillot and Sator (2011) where a silicate melt of a given composition is in equilibrium with a supercritical $\mathrm{CO}_{2}$ fluid, yields a solubility of about $25 \mathrm{wt} \% \mathrm{CO}_{2}$ at $2073 \mathrm{~K}$ and $8 \mathrm{GPa}$, a solubility value slightly higher than the $\mathrm{CO}_{2}$ content found in the experimental melt.

As one of our goal is to investigate the effect of the melt composition on the $\mathrm{CO}_{2}$ speciation, we have also simulated a basaltic composition in the CMAS system (namely, 49.1 wt.\% $\mathrm{SiO}_{2}, 17.4$ wt.\% $\mathrm{Al}_{2} \mathrm{O}_{3}, 17.3$ wt.\% $\mathrm{MgO}$ and 16.2 wt.\% $\mathrm{CaO}$ ), one of the melts investigated by Shaw (2004) in quartz dissolution experiments and which exhibits a relatively low liquidus temperature $(\sim 1753 \mathrm{~K})$. For convenience, the 
calculations have been performed at $8 \mathrm{GPa}$ and $2073 \mathrm{~K}$ with a $\mathrm{CO}_{2}$ amount of $20 \mathrm{wt} . \%$, a value which nearly corresponds to $\mathrm{CO}_{2}$ saturation, according to our own evaluation of the $\mathrm{CO}_{2}$ solubility in this melt by MD simulation (not shown). Note that in a recent experimental study aiming to evaluate the $\mathrm{CO}_{2}$ solubility in silicate melts at high pressure (Amalberti et al., 2011), it was concluded that the $\mathrm{CO}_{2}$ solubility in andesitic to basaltic composition at $1873 \mathrm{~K}$ and $8.5 \mathrm{GPa}$ is higher than $\sim 14 \mathrm{wt} . \%$.

We first performed classical MD simulations for the two melts under investigation in using the force field and the computational methodology of Guillot and Sator (2011). At $8 \mathrm{GPa}$ and $2073 \mathrm{~K}$, the $\mathrm{CO}_{2^{-}}$ bearing basaltic melt has a density of $3.04( \pm 0.03) \mathrm{g} / \mathrm{cm}^{3}$ and that of the kimberlitic composition is 3.03 $( \pm 0.03) \mathrm{g} / \mathrm{cm}^{3}$ whereas the densities of the $\mathrm{CO}_{2}$-free melts at the same thermodynamic conditions are 3.22 $( \pm 0.03)$ and $3.20( \pm 0.03) \mathrm{g} / \mathrm{cm}^{3}$, respectively. In Table 2 is given a comparison with PVT data of the literature. In the case of $\mathrm{CO}_{2}$-free melts, a good agreement is obtained with the compressibility data of Ai and Lange (2008) and Asimow and Ahrens (2010) for CMAS basalts and with the equation of state of Sakamaki et al. (2010) for a dry peridotite. In the case of $\mathrm{CO}_{2}$-bearing melts, a few experimental studies have been devoted to the volumetric properties of carbonated magmas (Ghosh et al., 2007; Sakamaki et al., 2011; Duncan and Agee, 2011; Seifert et al., 2013). A relevant quantity is the partial molar volume of carbon dioxide, $\overline{\mathrm{V}}_{\mathrm{CO}_{2}}$ which, in a first approximation, can be evaluated from the difference between the densities of the two melt compositions (with and without $\mathrm{CO}_{2}$ ) at the same thermodynamic conditions. One sees in Table 2 that the value of $\overline{\mathrm{V}}_{\mathrm{CO}_{2}}$ is similar in the two simulated melts and is compatible with that measured in various carbonated magmas. However, our evaluation is in general a little bit lower than the experimental data, may be a bias due to the approximation made $\left(\overline{\mathrm{V}}_{\mathrm{CO}_{2}}\right.$ is evaluated from the difference in density between the two melts and not from the derivative with respect to $\mathrm{CO}_{2}$ concentration) which is likely less accurate for the $\mathrm{CO}_{2}$-rich melts investigated here.

In order to save computer time, the FPMD calculations were not initiated from a randomized configuration but from atomic configurations generated with classical MD simulations. In order to avoid, as far as possible, a memory effect in carrying out FPMD calculations, the starting configuration for $\mathrm{CO}_{2^{-}}$ bearing melts did not correspond to a chemically equilibrated state (i.e. the ratio of $\mathrm{CO}_{2}$ molecules to carbonate ions in the starting configuration was fixed arbitrarily to $~ 1.0)$. Moreover, the FPMD calculations 
being performed in the canonical ensemble (NVT), the value assigned to the density of the melt under investigation was obtained from a classical MD simulation run in the isothermal-isobaric ensemble at $\mathrm{T}=$ 2073K and $\mathrm{P}=8 \mathrm{GPa}$ (i.e. 3.22 and $3.20 \mathrm{~g} / \mathrm{cm}^{3}$ for $\mathrm{CO}_{2}$-free basalt and kimberlite, and 3.04 and $3.03 \mathrm{~g} / \mathrm{cm}^{3}$ for the corresponding $\mathrm{CO}_{2}$-bearing melts). After a few ps of equilibration the FPMD pressure stabilized at about $12 \pm 2 \mathrm{GPa}$ in the $\mathrm{CO}_{2}$-bearing melts, around $11 \pm 2 \mathrm{GPa}$ in the $\mathrm{CO}_{2}$-free basaltic melt, and around 13 $\pm 2 \mathrm{GPa}$ in the $\mathrm{CO}_{2}$-free kimberlitic melt. Thus the pressure deduced from FPMD calculations is

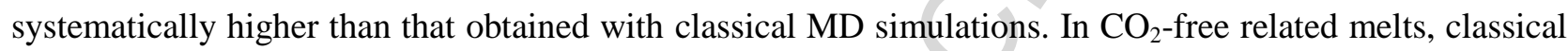
MD simulations give a pressure value closer to experiment (see Table 2 for a comparison). With regard to $\mathrm{CO}_{2}$-bearing melts, the rare density data on carbonated magmatic compositions (Ghosh et al., 2007; Sakamaki et al., 2011; Duncan and Agee, 2011; Seifert et al., 2013) are not sufficiently documented to evaluate further the accuracy of our results. However, both methods lead to the same value for the $\mathrm{CO}_{2}$ partial molar volume (see Table 2), because for both of them there is no pressure change between the $\mathrm{CO}_{2}$ free and the $\mathrm{CO}_{2}$-bearing melt.

\section{RESULTS}

\section{1 $\mathrm{CO}_{2}$ speciation and structure of the melt.}

The speciation of $\mathrm{CO}_{2}$ was evaluated by counting at each time step of the simulation (FPMD or classical MD) the number of $\mathrm{CO}_{2}$ molecules and the number of carbonate ions $\left(\mathrm{CO}_{3}^{2-}\right)$ present in the simulation cell. The running value of the ratio, $\mathrm{R}=\mathrm{N}_{\mathrm{CO}_{2}} /\left(\mathrm{N}_{\mathrm{CO}_{2}}+\mathrm{N}_{\mathrm{CO}_{3}^{2-}}\right)$, evaluated along the FPMD simulation is shown in Fig.1(lower panel) for the basaltic and the kimberlitic compositions. This ratio first decreases rapidly in the first $1 \sim 2$ ps and seems to stabilize around a stationary value characterized by large statistical fluctuations. The amplitude of these fluctuations is directly related to the small number of simulated particles (here $\mathrm{N}=640$ ) as it scales with the square root of this number. A drastic decrease of the statistical noise (let us say by a factor of 10 ) would require to simulate a system size (e.g. $\mathrm{N}=640 \times 100$ ) intractable by FPMD calculation with usual computing resources. Furthermore, at first view the simulation time seems to be too short ( $22 \mathrm{ps})$ to assure that equilibration is reached. Unfortunately, ab initio calculations being very highly demanding in computing resources, it is not possible to carry on the FPMD calculation over a much longer simulation time (e.g. 100 ps or more). Hence, it is necessary to get some 
clue from other sources of information. Therefore we have evaluated the time evolution of the concentration ratio $\mathrm{R}$ by classical MD over a simulation time of 1 ns (i.e. $\times 50$ as long as the FPMD simulation time). The running value of $\mathrm{R}$ exhibits a fast decay in the first few ps leading to a steady state after roughly 15 ps (see upper panel in Fig.1), a steady state characterized by statistical fluctuations as large as those observed with FPMD calculations since the system size is the same in the two calculations. In fact, very little information is gained when the simulation run is continued far beyond $20 \mathrm{ps}$ (see the insert in Fig.1). This is confirmed by an analysis of the statistical fluctuations based upon the evaluation of the correlation time associated with the self-correlation function of the concentration ratio $(\langle\mathrm{R}(\mathrm{t}) \mathrm{R}(0)\rangle)$. This self-correlation function (not shown) decreases exponentially with a decay time equal to $3.7 \mathrm{ps,}$, which means that beyond this time, $\mathrm{R}(\mathrm{t})$ reaches rapidly its equilibrium value in exhibiting uncorrelated fluctuations around this value.

Another information comes from the theory of chemical kinetics (Benson, 1960) which stipulates that for a second order reaction $\left(\mathrm{CO}_{3}^{2-} \underset{k_{1}, k_{2}}{\Longleftrightarrow} \mathrm{CO}_{2}+\mathrm{O}^{2-}\right)$, the time evolution of the concentration ratio $\mathrm{R}$ is monoexponential with a decay time depending at once on the rate constants $k_{1}$ and $k_{2}$, and on the initial concentrations of the reactants (for details see Benson, 1960). A rapid look at Fig.1 shows that the time evolution of $\mathrm{R}(\mathrm{t})$ issued from the FPMD or the classical MD calculations follows the kinetics law (the rate constants $k_{1}$ and $k_{2}$ have been fitted to reproduce at best the initial decay of $\left.\mathrm{R}(\mathrm{t})\right)$. The important conclusion is that the steady state is reached after a few ps only, the reaction kinetics developing essentially at short times without exhibiting a long time contribution.

In summary, we believe that our FPMD calculations lead to a reasonable estimation of the concentration ratio $\mathrm{R}$ in spite of large statistical fluctuations generated by the small number of simulated atoms. Thus, the average of R, evaluated in leaving out the fast initial decay (i.e. in averaging over the time range between 2 and 22 ps, see Fig.1), is equal to $0.15 \pm 0.08$ in the basaltic melt while it amounts to $0.02 \pm$ 0.02 in the kimberlitic melt. For comparison, a proportion of $\mathrm{CO}_{2}$ molecules about $\sim 0.23 \pm 0.08$ is found in the basaltic melt simulated by classical $\mathrm{MD}$, whereas in the kimberlitic composition the proportion of $\mathrm{CO}_{2}$ molecules is found to be slightly lower $(\sim 0.18 \pm 0.08)$. These latter results were obtained in performing the MD calculations at the same density than the FPMD ones (see Table 1). But knowing that the $\mathrm{CO}_{2}$ speciation evolves significantly with the pressure (after Guillot and Sator (2011), the higher the pressure, 
the lower the proportion of $\mathrm{CO}_{2}$ molecules in the melt) we have re-evaluated the concentration ratio $\mathrm{R}$ by classical MD at $\mathrm{P}=12 \mathrm{GPa}$ (instead of $8 \mathrm{GPa}$ ), i.e. at the pressure reached in the FPMD calculations. As expected the proportion of $\mathrm{CO}_{2}$ molecules decreases upon increasing the pressure to $12 \mathrm{GPa}$ and equilibrates about $\sim 0.11 \pm 0.06$ in the basaltic melt and about $\sim 0.08 \pm 0.05$ in the kimberlitic composition. Thus, with regard to the basaltic composition, the two calculations (FPMD versus MD) give similar results for $\mathrm{R}$ when one takes into account the uncertainty on the pressure. Hence one may conclude that at superliquidus temperature and high pressure a non-negligible proportion of $\mathrm{CO}_{2}$ molecules (more than 10 $\%)$ are present in $\mathrm{CO}_{2}$-rich basaltic magmas. In contrast the effect of the melt composition on the $\mathrm{CO}_{2}$ speciation is much more marked with FPMD than with $\mathrm{MD}$ since the concentration in $\mathrm{CO}_{2}$ molecules decreases strongly with FPMD in going from basaltic to kimberlitic composition (by roughly one order of magnitude) whereas it decreases very little with MD. This finding suggests that the empirical force field used to describe the reactivity of $\mathrm{CO}_{2}$ in silicate melts by classical MD needs to be improved.

The carbonate ions occurring in FPMD simulations are planar on average, with a most frequent C-O bond length equal to $1.27 \mathrm{~A}$ and an $\mathrm{O}-\mathrm{C}-\mathrm{O}$ bond angle close to $120^{\circ}$ (see Fig. 2). Furthermore, the bond length and bond angle distributions are rather large (with $\Delta_{1 / 2} R_{\mathrm{C}-\mathrm{O}}=0.2 \mathrm{~A}$ and $\Delta_{1 / 2} \theta_{\mathrm{O}-\mathrm{C}-\mathrm{O}}=20^{\circ}$ ), features indicating that the $\mathrm{CO}_{3}^{2-}$ groups are somewhat distorted due to their interactions with the silicate structure (see below for further details). Moreover, in the basaltic melt the $\mathrm{CO}_{2}$ molecules are slightly bent (the maximum of the O-C-O bond angle distribution is at about $163^{\circ}$ ) which suggests that the molecules interact strongly with the silicate network. More importantly, in addition to molecular $\mathrm{CO}_{2}$ and carbonate ions, a new species is found in the basaltic melt, the pyrocarbonate (or dicarbonate) anion $\mathrm{C}_{2} \mathrm{O}_{5}^{2-}$. Although, on average, only 2 pyrocarbonate anions are present in the simulation, this number corresponds to $\sim 3.7 \%$ of all the C-species, a proportion not quite negligible. It is noteworthy that this species is transient in the basaltic melt and acts as an intermediate species with a mean lifetime of about 175 fs and a maximum observed lifetime of $550 \mathrm{fs}$ (this lifetime corresponds to a few tens of oscillation of the C-O-C bridge in the $\mathrm{C}_{2} \mathrm{O}_{5}$ moiety). The existence of the pyrocarbonate anion was suggested at the end of the nineties for explaining the high solubility of $\mathrm{CO}_{2}$ in pure molten carbonates (Claes et al., 1999) and gas phase ab initio calculations have shown that $\mathrm{C}_{2} \mathrm{O}_{5}^{2-}$ is energetically stable (Peeters et al., 1999a,b; Bruna et al., 2011). 
Since then, it has been observed with Raman spectroscopy in exposing molten carbonate mixtures to a $\mathrm{CO}_{2}$ atmosphere (Zhang et al., 2013). The occurrence of a pyrocarbonate ion comes from the association of a $\mathrm{CO}_{2}$ molecule with an $\mathrm{CO}_{3}^{2-}$ anion or equivalently, an oxide ion of the melt captures two $\mathrm{CO}_{2}$ molecules to form the symmetrical dianion $\left(\mathrm{O}_{2} \mathrm{C}-\mathrm{O}-\mathrm{CO}_{2}\right)^{2-}$. The analysis of the FPMD-generated atomic configurations shows that the dianion is (on average) symmetrical with a most probable $\mathrm{R}_{\mathrm{C}-\mathrm{O} *}$ distance between the central oxygen atom $\mathrm{O}^{*}$ and the two carbon atoms equal to $1.42 \mathrm{~A}$, the two lateral $\mathrm{CO}_{2}$ units being equivalent with a C-O bond length about $1.23 \mathrm{~A}$ and a $\mathrm{O}-\mathrm{C}-\mathrm{O}$ angle of $\sim 125^{\circ}$ (see Fig.2). However the $\mathrm{C}-\mathrm{O} *-\mathrm{C}$ bridge is bent (with a most frequent angle of $\sim 115^{\circ}$ ) and exhibits motions of large amplitude (see Fig.2 for the distribution in $\mathrm{O}^{*}$-C distance). These results are in good agreement with gas phase ab initio calculations of the free dianion (e.g. $\mathrm{R}_{\mathrm{C}-\mathrm{O}^{*}} \sim 1.44 \mathrm{~A}, \mathrm{R}_{\mathrm{C}-\mathrm{O}} \sim 1.26-1.27 \mathrm{~A}, \mathrm{C}-\mathrm{O} *-\mathrm{C} \sim 134^{\circ}$, and $\mathrm{O}-\mathrm{C}-\mathrm{O} \sim 130^{\circ}$, according to Peeters et al., 1999b). Notice that the occurrence of pyrocarbonate ions in the basaltic melt is also predicted in our classical MD simulation, but in a much smaller proportion $(\sim 0.4 \%)$.

An important question that can be investigated with the help of the FPMD calculations concerns the solvation structure of carbonate ions (and $\mathrm{CO}_{2}$ molecules) in silicate melts. To quantify the melt structure at the atomic scale it is usual to evaluate the atom-atom pair distribution functions (PDF), $g_{i j}(R)$, where $i$ and $j$ are atoms of species $i$ and $j$, and $R$ is the distance between these atoms. In a PDF curve, the successive peaks correspond to the successive shells of neighbors around a given atomic species and the minima between peaks delimit the extension of the shells (Billinge and Kanadzitis, 2004). However, the absence of a long range order in a liquid makes that the successive peaks in the PDFs are rapidly damped beyond a few molecular diameters. To quantify the local structure around $\mathrm{CO}_{2}$ and $\mathrm{CO}_{3}^{2-}$ species, we have evaluated the PDFs between the carbon atom and the elements of the silicate melt (in Fig.3, the full curves were obtained from the FPMD calculations by averaging over the time range 2-22 ps where the $\mathrm{CO}_{2} / \mathrm{CO}_{3}$ ratio is approximately constant as shown in Fig.1). Thus in the basaltic composition, the carbon-oxygen PDF, $\mathrm{g}_{\mathrm{OC}}(\mathrm{R})$, exhibits an intense and narrow first peak corresponding to the $\mathrm{C}-\mathrm{O}$ bond length in $\mathrm{CO}_{2}$ molecules and in carbonate ions at 1.16 and $1.27 \mathrm{~A}$, respectively. In the kimberlitic melt only the C-O bond length associated with the carbonate ion appears in $\mathrm{g}_{\mathrm{OC}}(\mathrm{R})$ at $1.27 \mathrm{~A}$ since the concentration in $\mathrm{CO}_{2}$ molecules is vanishingly small in this melt. The second peak seen in $\mathrm{g}_{\mathrm{OC}}(\mathrm{R})$ is broad in the two melts and presents a maximum at about 
3.6 A. The latter one corresponds to oxygens of the first solvation shell around a C-species $\left(\mathrm{CO}_{2}\right.$ or $\left.\mathrm{CO}_{3}^{2-}\right)$ which are not chemically bonded with it. With regard to $g_{O O}(R)$, the shoulder occurring on its low-r flank at about $2.30 \mathrm{~A}$ is produced essentially by the $\mathrm{O}-\mathrm{O}$ intramolecular distances in $\mathrm{CO}_{3}^{2-}$ ions (as for the $\mathrm{O}-\mathrm{O}$ distance associated with $\mathrm{CO}_{2}$ molecules in the basaltic melt, it falls in the same range). In passing one notices that the PDFs, $g_{O O}(R)$ and $g_{O C}(R)$, issued from the classical MD simulations (see the dotted curves in Fig.3) are close to those obtained from FPMD calculations except for the position of the O-O peak ( 2.0 A instead of 2.30 A by FPMD), a deviation due to the force field used in classical MD simulations in which the carbonate ions are described as slightly asymmetrical (see Guillot and Sator, 2011).

With regard to the correlations between the $\mathrm{C}$-species and the network forming cations ( $\mathrm{Si}$ and $\mathrm{Al}$ ), the first peak centered at about $2.7 \mathrm{~A}$ in $\mathrm{g}_{\mathrm{SiC}}(\mathrm{R})$ and $2.8 \mathrm{~A}$ in $\mathrm{g}_{\mathrm{AIC}}(\mathrm{R})$ corresponds to C-O...Si and C-O..Al bonds between a carbonate ion and a $\mathrm{Si}$ or $\mathrm{Al}$ atom. One notices a high selectivity of $\mathrm{Al}$ with respect to carbonate ions in the basaltic melt (see below). As for the mean distances $R_{\mathrm{CaC}}=3.1 \mathrm{~A}$ and $\mathrm{R}_{\mathrm{MgC}}=2.9 \mathrm{~A}$ between a carbonate ion and the closest alkali earth cations $(\mathrm{Ca}$ and $\mathrm{Mg})$, as evaluated from the position of the maximum of the first peak in $\mathrm{g}_{\mathrm{CaC}}(\mathrm{R})$ and $\mathrm{g}_{\mathrm{MgC}}(\mathrm{R})$, they are quite similar to those observed in molten carbonates (see Vuilleumier et al., 2014). It is noteworthy that the classical MD simulations predict a stronger binding of carbonate ions with $\mathrm{Si}$ in the two melts and a lower binding with $\mathrm{Al}$ in the basaltic melt whereas the $\mathrm{Ca}-\mathrm{C}$ and $\mathrm{Mg}-\mathrm{C}$ correlations are more pronounced in FPMD calculations.

In order to further describe the solvation structure around $\mathrm{CO}_{3}^{2-}$ species, we have evaluated the proportion of bridging (BC), non-bridging (NBC) and free carbonate ions (FC). A carbonate ion is defined as a $\mathrm{BC}$ or a NBC if it is connected to two or one, respectively, network-forming cations ( $\mathrm{Si}$ or $\mathrm{Al}$ ) of the melt. Alternatively, a carbonate ion is a NBC if it is connected to only one network- forming cations. In the case where a carbonate ion is connected to network-modifying cations ( $\mathrm{Ca}$ or $\mathrm{Mg}$ ) only, it is a $\mathrm{FC}$. In our calculation an oxygen of the carbonate ion is considered as connected to a network-forming cation if the cation-oxygen separation is smaller than the distance associated with the position of the first minimum shown by the PDF under investigation (e.g. 2.30 A for $\mathrm{Si}-\mathrm{O}$ and 2.55 A for $\mathrm{Si}-\mathrm{Al}$ ). The proportions of BC, NBC, and FC in the two simulated melts are summarized in Fig.4 as function of the nature of the network-forming cations ( $\mathrm{Si}$ or $\mathrm{Al}$ ) involved in the connectivity. In the basaltic melt there are $30.8 \%$ of $\mathrm{BC}, 48.6 \%$ of NBC 
and $20.6 \%$ of FC. Notice that classical MD calculations predict slightly different values, namely, $25.2 \%$ of BC, $67.6 \%$ of NBC, and $7.3 \%$ of FC. Among the population of BC evaluated in FPMD, the connectivity of carbonate ions with $\mathrm{Al}$ is overrepresented with respect to that with $\mathrm{Si}$ (the ratio $\mathrm{Al} / \mathrm{Si}=0.42$ in the melt and yet the population ratio $\left(\mathrm{Al}-\mathrm{CO}_{3}^{2-}-\mathrm{Al}\right) /\left(\mathrm{Si}-\mathrm{CO}_{3}^{2-}-\mathrm{Si}\right)$ is about $\left.\sim 4\right)$. For comparison, in the $\mathrm{CO}_{2}$-free basaltic melt, the respective proportions of bridging oxygens (BO), non-bridging oxygens (NBO) and free oxygens (FO) are different with a majority of $\mathrm{BOs}(\mathrm{BO}=61 \%$ and $\mathrm{NBO}=39 \%)$ and without free oxygens (Vuilleumier et al., 2009). Thus the distribution of carbonate ions within the melt is not similar to that of the oxygen atoms (BO and $\mathrm{NBO}$ ) of the silicate network. In particular the number of oxygens belonging to free carbonate ions only interacting with alkaline earth cations is significant $(\mathrm{FC} \sim 21 \%)$.

From the basaltic to the kimberlitic composition the population of $\mathrm{BC}$ decreases from 30.8 to $2.7 \%$, that of NBC from 48.6 to $21.9 \%$, whereas, the population of FC becomes as high as $75.4 \%$ (classical MD only predicts $33.8 \%$ of FCs). Thus when $\mathrm{CO}_{2}$ is dissolved into the kimberlitic melt an overwhelming majority of carbonate ions are FC solvated by alkali earth cations ( $\mathrm{Mg}$ and $\mathrm{Ca}$ ), a situation encountered both in molten carbonates and carbonatites. So the $\mathrm{CO}_{2}$-bearing kimberlitic melt can be viewed as a silicate melt having incorporated a carbonatitic component.

\subsection{Influence of $\mathrm{CO}_{2}$ on the transport properties of silicate melts.}

The effect of $\mathrm{CO}_{2}$ on the transport properties of silicate melts is poorly known and somewhat controversial. Brearley and Montana (1989) reported that by adding $0.5 \mathrm{wt} \% \mathrm{CO}_{2}$ in albite melt the viscosity is reduced by a factor of $1.5-1.2$ in the pressure range $15-25$ kbar at $1400^{\circ} \mathrm{C}$ whereas no detectable change in viscosity is observed by adding $2 \mathrm{wt} \% \mathrm{CO}_{2}$ in sodamelilite melt at $15-20 \mathrm{kbar}$ and $1450^{\circ} \mathrm{C}$. Subsequently, White and Montana (1990) indicated that $\mathrm{CO}_{2}$ reduces significantly the viscosity of liquid sanidine under all conditions of $\mathrm{CO}_{2}$ concentration (up to a factor of 7 with $1.5 \mathrm{wt} \%$ $\mathrm{CO}_{2}$ at $25 \mathrm{kbar}$ and $1500^{\circ} \mathrm{C}$ ). Later on, Bourgue and Richet (2001) showed that $3.5 \mathrm{wt} \% \mathrm{CO}_{2}$ could be dissolved at 1 bar in a potassium silicate liquid with $56.9 \mathrm{~mol} \% \mathrm{SiO}_{2}$, leading to a two order of magnitude decrease of the viscosity near the glass transition temperature $(\sim 750 \mathrm{~K})$. However, the effect of $\mathrm{CO}_{2}$ on the viscosity becomes undetectable above $\sim 1,000 \mathrm{~K}$. More recently, Morizet et al. (2007) used differential scanning calorimetry to investigate the effect of $\mathrm{CO}_{2}$ (in the concentration 
range $0.6-2.3 \mathrm{wt} \%$ ) on the glass transition temperature of jadeite and phonolite glasses and concluded due to the absence of any measurable effect that $\mathrm{CO}_{2}$ contributes very little to changes in the properties of these melts. In this context it is valuable to investigate the effect of a very high concentration in $\mathrm{CO}_{2}$ (e.g. $\sim 20 \mathrm{wt} \%$ ) on the transport properties of the melts investigated here.

Because an accurate evaluation of the viscosity of a silicate melt at around $2100 \mathrm{~K}$ by FPMD calculations is out of reach in a reasonable computer time (viscosity is a slowly converging quantity by simulation, see Hess (2002)), we have focused our investigation on the self-diffusion coefficients of the elements of the melt ( $\mathrm{Si}, \mathrm{Al}, \mathrm{Ca}, \mathrm{Mg}$ and $\mathrm{C}$ ). Notice that the evaluation of the self-diffusion coefficient of oxygen atoms is inaccurate and has not been reported because of the rapid exchange between the oxygens of the carbonate ions and those of the silicate melt. The self-diffusion coefficients have been evaluated from the relation (Kubo, 1966),

$\mathrm{D}_{\mathrm{s}}=\lim _{\mathrm{t} \rightarrow \infty} \frac{1}{\mathrm{~N}_{\mathrm{s}}} \sum_{\mathrm{i}=1}^{\mathrm{N}_{\mathrm{s}}} \frac{<\left(\mathrm{r}_{\mathrm{i}}(\mathrm{t})-\mathrm{r}_{\mathrm{i}}(0)\right)^{2}>}{6 \mathrm{t}}$,

where $\mathbf{r}_{\mathrm{i}}$ is the position of the particle $\mathrm{i}$ of species $\mathrm{s}$ and the bracket expresses an ensemble average taken over many time origins of the simulation. Notice that the diffusive regime is reached when the time evolution of the mean square displacement (MSD) describes a straight line of slope equal to 1 in a $\log (\mathrm{MSD})$ versus $\log (\mathrm{t})$ representation. Some examples obtained with FPMD and MD calculations are given in Fig.5. It is clear that the diffusive regime is established in the 5-10 ps range according to the investigated elements. Values of the self-diffusion coefficients of ions and $\mathrm{C}$-species in $\mathrm{CO}_{2}$-free and $\mathrm{CO}_{2}$-bearing melt are collected in Table 3. The uncertainties on $\mathrm{D}_{\mathrm{s}}$ are rather large with FPMD calculations $( \pm 30 \%)$, due to the short duration of the simulation runs $(\sim 20 \mathrm{ps})$, whereas they are much smaller with MD calculations ( $\pm 10 \%$ for a running time of $10 \mathrm{~ns}$ ).

In $\mathrm{CO}_{2}$-free melts the values calculated from FPMD are compatible with ionic diffusivity data in basaltic liquids and in diopside liquid, the latter one being a good proxy for a depolymerized melt like kimberlite (see Table 3 for a comparison). Notice also that in the two investigated compositions, the calculated diffusion coefficients of the network forming cations $\mathrm{Si}$ and $\mathrm{Al}$ are not very different from that shown by the network modifying cations, $\mathrm{Mg}$ and $\mathrm{Ca}$, a feature due to the high temperature of investigation and which characterizes melts of low viscosity $(\ll<1$ Pa.s). In contrast, in melts of high 
viscosity (> 1 Pa.s), the latter one is governed essentially by the low diffusivity of structure maker ions, network modifying cations exhibiting much larger self-diffusion coefficients. In fact the viscosity of silicate melts varies strongly with temperature and pressure. When the temperature behavior of the melt viscosity is monotonic (higher the temperature lower the viscosity), the evolution with pressure is more complex and depends on melt composition and temperature. Therefore the viscosity of a MORB melt at $1873 \mathrm{~K}$ goes through a minimum value with pressure (around 3.4 GPa after Ando et al., 2003) whereas it decreases steadily at $2023 \mathrm{~K}$ with a value of about $\sim 0.3 \mathrm{~Pa} . \mathrm{s}$ at $5.2 \mathrm{GPa}$ (as compared with $\sim 0.8$ Pa.s at 1 bar). In contrast, the viscosity of liquid diopside (Reid et al., 2003) and of liquid peridotite (Liebske et al., 2005) at $2073 \mathrm{~K}$ go through a maximum with pressure (about $0.5 \mathrm{~Pa} . \mathrm{s}$ for diopside and 0.16 Pa.s for peridotite at $8 \mathrm{GPa}$ ), whereas that of liquid fayalite, a very depolymerized melt, always decreases with the pressure and becomes as low as 0.03 Pa.s at $2073 \mathrm{~K}$ and 8 GPa (Spice et al., 2014). In summary, the viscosity of moderately and highly depolymerized melts is low at high temperature and high pressure and falls within the same order of magnitude $(\sim 0.1-1 \mathrm{~Pa} . \mathrm{s}$ at $8 \mathrm{GPa}$ according to Suzuki et al. (2005) and Mueller et al. (2010)). Hence, the above viscosity data suggest that the self-diffusion coefficients of structure maker ions in our melts are likely high and of the same order of magnitude that those associated with structure modifier ions, a trend which is observed in the present study.

With regard to $\mathrm{CO}_{2}$-bearing melts, an important finding from our study is that the presence of a high concentration of $\mathrm{CO}_{2}(\sim 20 \mathrm{wt} . \%)$ has virtually no effect on the self-diffusion coefficients of elements in the basaltic melt (see Table 3) and a very limited effect in the kimberlitic melt (about a 25-50\% increase of the diffusivity of $\mathrm{Si}, \mathrm{Al}, \mathrm{Mg}$ and $\mathrm{Ca}$ ). As for the self-diffusion coefficient of carbon atoms, it has practically the same value in the two melts and it is close to the one of $\mathrm{Ca}$. In the basaltic melt we have made an attempt to evaluate the self-diffusion coefficient of molecular $\mathrm{CO}_{2}$ by following during the simulation run the carbon atoms belonging (transiently) to $\mathrm{CO}_{2}$ molecules only. The result of this evaluation leads to a value $D_{\mathrm{CO}_{2}} \sim 1.10^{-9} \mathrm{~m}^{2} / \mathrm{s}$, that is more than twice as high as the one associated with carbonate ions, $D_{\mathrm{CO}_{3}} \sim 0.410^{-9} \mathrm{~m}^{2} / \mathrm{s}$ (this value is deduced from the approximate relation, $D_{C}=x D_{C O_{3}}+(1-x) D_{C O_{2}}$, where $\mathrm{x}=0.85$ is the proportion of carbonate ion in the melt, 
and $D_{C} \sim 0.510^{-9} \mathrm{~m}^{2} / \mathrm{s}$, the diffusion coefficient of carbon atoms). Although the uncertainty of this evaluation is high, this result is in agreement with the evaluation of Nowak et al. (2004) in haplobasaltic melts $\left(D_{\mathrm{CO}_{2}} / D_{\mathrm{CO}_{3}} \sim 3\right.$ at $1673 \mathrm{~K}$ and $0.5 \mathrm{GPa}$ with 0.2 wt. $\left.\% \mathrm{CO}_{2}\right)$. With regard to the kimberlitic melt, where the concentration in $\mathrm{CO}_{2}$ molecules is very low, the self-diffusion coefficient of carbon is a good proxy for the one associated with carbonate ions. As for the classical MD calculations it is noteworthy that the values of the self-diffusion coefficients, and especially for $\mathrm{Mg}$ and $\mathrm{Ca}$, are markedly larger than those evaluated from FPMD (up to a factor of two or three, see Table 3). In fact it is documented (Bauchy et al., 2012) that the force field used in our classical MD simulations lead to melts which are not sufficiently viscous (e.g. the calculated viscosity for a MORB melt at $2073 \mathrm{~K}$ and $5.2 \mathrm{GPa}$ is equal to $\sim 0.04 \mathrm{~Pa} . \mathrm{s}$ (Bauchy et al., 2012) as compared with an experimental value about $\sim 0.3$ Pa.s (Ando et al., 2003)).

A transport property which plays a key role for interpreting magnetotelluric data in the asthenosphere is the electrical conductivity (for a review Pommier, 2014). We have evaluated the electrical conductivity of our simulated melts by applying the following relation (Kubo, 1966),

$\sigma=\frac{1}{\mathrm{k}_{\mathrm{B}} \mathrm{TV}} \lim _{\mathrm{t} \rightarrow \infty} \frac{1}{6 \mathrm{t}}<\left|\sum_{\mathrm{i}=1}^{\mathrm{N}} \mathrm{z}_{\mathrm{i}}\left(\mathbf{r}_{\mathrm{i}}(\mathrm{t})-\mathbf{r}_{\mathrm{i}}(0)\right)\right|^{2}>$

where $\mathrm{V}$ is the volume of the sample, $\mathbf{r}_{\mathrm{i}}$ is the position of the ion $\mathrm{i}, \mathrm{z}_{\mathrm{i}}$ its electric charge, and the angular brackets again express an average taken over many time origins. As in the case of the selfdiffusion coefficient, the evaluation of the conductivity from Eq.(3) is precise as long as the diffusive regime is reached, i.e. when the mean square displacement of the charges describes a straight line in a $\log -\log$ representation. In practice the diffusive regime is reached after $\sim 2$ ps in the kimberlitic melt and after $\sim 4$ ps in the basaltic melt (not shown). However, the statistical uncertainty on $\sigma$ is rather large with FPMD $( \pm 30 \%)$ and much weaker with MD $( \pm 10 \%)$. In Table 3 are reported the values of $\sigma_{f v}$ obtained considering that the electric charges, $\mathrm{z}_{\mathrm{i}}$, assigned to the elements of the melt are equal to the formal values (i.e. $\mathrm{z}_{\mathrm{O}}=-2 \mathrm{e}, \mathrm{z}_{\mathrm{Si}}=+4 \mathrm{e}, \mathrm{z}_{\mathrm{Al}}=+3 \mathrm{e}, \mathrm{z}_{\mathrm{Mg}}=+2 \mathrm{e}, \mathrm{z}_{\mathrm{Ca}}=+2 \mathrm{e}$, and $z_{C}=+4 \mathrm{e}$ ). It is noteworthy that the evaluation of the electrical conductivity by Eq.(3) is precise as long as the charges of the ions are well defined. For instance in a molten salt like $\mathrm{NaCl}$ which is fully ionic, the charges associated with $\mathrm{Na}$ and $\mathrm{Cl}$ can be set equal to $+1 \mathrm{e}$ and $-1 \mathrm{e}$, respectively, and it has been shown that the 
use of formal charges $\left(z_{\mathrm{Ca}^{2+}}=+2 \mathrm{e}\right.$ and $\left.z_{\mathrm{CO}_{3}^{2-}}=-2 \mathrm{e}\right)$ is also suitable to investigate molten calcium carbonate which behaves as a molten salt (Vuilleumier et al., 2014). With silicate melts the situation is different (see the discussion below).

Inspection of Table 3 shows that the FPMD conductivities of the $\mathrm{CO}_{2}$-free melts at $\sim 11 \mathrm{GPa}$ and $2073 \mathrm{~K}$ are high, the kimberlitic composition being more conductive than the basaltic one $(\sim 171 \pm 50$ $\mathrm{S} / \mathrm{m}$ as compared with $\sim 105 \pm 30 \mathrm{~S} / \mathrm{m}$ ). This latter result suggests that the electrical conductivity of Naand K-free melts at high temperature and pressure increases when the degree of polymerization of the melt decreases. The new result is that $\mathrm{CO}_{2}$ increases very little the conductivity of the basaltic melt ( $140 \pm 40$ instead of $\sim 105 \pm 30 \mathrm{~S} / \mathrm{m})$, and barely changes that of the kimberlitic melt $(\sim 150 \pm 45$ instead of $\sim 171 \pm 50 \mathrm{~S} / \mathrm{m})$. In fact, these results are not surprising if one remembers that the diffusion of the elements into the silicate melts is not (or very little) influenced by the presence of $\mathrm{CO}_{2}$ and that the carbonate ions are not more mobile than $\mathrm{Ca}$ and $\mathrm{Mg}$ cations (see Table 3).

\subsection{Comparison with electrical conductivity data of carbonated basalts.}

From the experimental point of view the electrical conductivity of anhydrous basaltic liquids is about $30 \mathrm{~S} / \mathrm{m}$ at $2073 \mathrm{~K}$ and 1 bar (Waff and Weill, 1975; Tyburczy and Waff, 1983; Ni et al., 2011a) and $\sim 17 \mathrm{~S} / \mathrm{m}$ at $2 \mathrm{GPa}$ (Tyburczy and Waff, 1983; Ni et al., 2011a) but its behavior is not known at a higher pressure. With regard to the conductivity of the $\mathrm{CO}_{2}$-free kimberlitic composition, at superliquidus temperature and low pressure it is likely of the same order of magnitude than that of ultramafic melts (e.g. 30-50 S/m at $2073 \mathrm{~K}$ and 1 bar according to Rai and Manghnani, 1978), but the evolution with pressure is not documented. Consequently, in keeping in mind the above estimations, one is led to the conclusion that the FPMD calculations ( 105-171 S/m, see Table 3 for a comparison) could overestimate by a factor of $\sim 4-5$ the conductivity of the $\mathrm{CO}_{2}$-free silicate melts. With regard to the MD calculations the situation is even worse since the overestimation may reach one order of magnitude (Table 3).

However, the electrical conductivity has been calculated in assuming that the melt is composed of ions bearing their formal charge (i.e. $z_{O}=-2 e$ in Eq.(3), the charge of the cations being deduced from the electro-neutrality of the associated metal oxides). In fact, the interactions between the atoms of the 
silicate melt are partially ionic and partially covalent with strong polarization effects, and on average the electric charge on each atom is much smaller than the one assigned by standard chemistry. Thus, to take into account in an effective way the complexity of the interactions, the empirical force fields of the literature based upon a rigid ion model (i.e. without ionic polarizability) make use of effective charges which are roughly half of the formal values. For instance the TTAM and BKS potentials (Tsuneyuki et al., 1988; van Beest et al., 1990), two popular models for describing the various polymorphs of silica and which are fitted on Hartree-Fock calculations of a tetrahedral $\mathrm{SiO}_{4}$ cluster charge-saturated by four hydrogen atoms, lead to effective charges $z_{O}=-z_{S i} / 2=-1.2 e$. Another approach is to run a classical MD simulation using effective charges and to perform a FPMD calculation for benchmark. From these two calculations and with the help of a minimization procedure (force matching or structure matching), one is able to deduce an optimal set of effective charges to implement in the empirical force field. Following this procedure, Carré et al. (2008) have determined an effective charge equal to -0.955 e for oxygen atoms in liquid silica, whereas Beck et al. (2012) when investigating various metal oxides, found a value of $-0.90 \mathrm{e}$ in liquid silica, $-1.10 \mathrm{e}$ in liquid magnesia and $-0.83 \mathrm{e}$ in liquid alumina. These values are very close to the effective charge for oxygen, $\mathrm{z}_{\mathrm{O}}=-$ 0.945e, introduced by Guillot and Sator (2007a,b) in their empirical force field for silicate melts, and that we use in the present classical MD simulations. So we have recalculated the electrical conductivity of the melts simulated by FPMD using in Eq.(3) the effective values of the ionic charges implemented in the empirical potential (i.e. $\mathrm{z}_{\mathrm{O}}=-0.945 \mathrm{e}, \mathrm{z}_{\mathrm{Si}}=+1.89 \mathrm{e}, \mathrm{z}_{\mathrm{Al}}=+1.4175 \mathrm{e}, \mathrm{z}_{\mathrm{Mg}}=+0.945 \mathrm{e}$, $\mathrm{z}_{\mathrm{Ca}}=+0.945 \mathrm{e}$ and, $\left.z_{C}=+1.89 \mathrm{e}\right)$. In the case of the MD calculations, the use of the effective charges in Eq.(3) is quite consistent, since they have been adjusted with the force field.

Because the conductivity scales as $\mathrm{z}_{\mathrm{i}}^{2}$ (see Eq.(3)), its magnitude drops by a large factor $(\sim 4.48)$ when the above effective charges are substituted for formal charges. The conductivity of the $\mathrm{CO}_{2}$-free basaltic melt simulated by FPMD now amounts to $\sim 23 \pm 7 \mathrm{~S} / \mathrm{m}$ and that of the $\mathrm{CO}_{2}$-free kimberlitic composition about $\sim 38 \pm 10 \mathrm{~S} / \mathrm{m}$, values which are in a fair agreement with conductivity data on dry basaltic and ultramafic melts at low pressure ( 17.5 and 30-50 S/m, see Table 3). But this conclusion must be tempered because the effect of the pressure ( $11 \mathrm{Gpa}$ is the pressure in the FPMD simulation) on the conductivity of dry basic and ultrabasic melts is not known (however, in albite melt, Ni et al. 
(2011b) have shown that the conductivity tends to decrease when the pressure increases from 1.8 to 6 and $10 \mathrm{GPa}$, but this decrease is almost cancelled when the temperature is higher than $\sim 2000 \mathrm{~K}$ ). As for the conductivities deduced from the classical MD simulations, they are still overestimated by a factor 2-3 (see Table 3).

In the $\mathrm{CO}_{2}$-bearing melts, the conductivities calculated from FPMD with effective charges $(\sim 31 \pm 9$ $\mathrm{S} / \mathrm{m}$ for the basaltic melt and $\sim 34 \pm 10 \mathrm{~S} / \mathrm{m}$ for the kimberlitic melt, see Table 3) can be compared with the rare data in the literature. Yoshino et al. (2012) have measured the electrical conductivity in a partial melting experiment of a carbonated peridotite (a spinel lherzolite $+1-3 \mathrm{wt} \%$ dolomite). At 1700 $\mathrm{K}$ and $3 \mathrm{GPa}$, and at a melt fraction of $20 \%$, the residual melt has an alkali-rich basaltic composition (similar to the one investigated here) with $13 \mathrm{wt} \% \mathrm{CO}_{2}$. The conductivity of the bulk melt is estimated to be in the range 10-30 S/m (for details see Yoshino et al. (2012)). Lately, Sifré et al. (2014) have measured the conductivity of several hydrous carbonated basalts at $3 \mathrm{GPa}$ in the temperature range 1173-1773 K. Among the investigated compositions, the HCB-4 composition ( 31 wt.\% $\mathrm{SiO}_{2}$ with 4.4 wt. $\% \mathrm{H}_{2} \mathrm{O}$ and 10.4 wt. $\% \mathrm{CO}_{2}$ ) falls between the kimberlitic and the basaltic composition investigated here. This hydrous carbonated melt exhibits conductivity equal to $\sim 59 \mathrm{~S} / \mathrm{m}$ at $1700 \mathrm{~K}$. In considering that a basaltic melt with 4.4 wt. $\% \mathrm{H}_{2} \mathrm{O}$ shows a conductivity value around $\sim 25 \mathrm{~S} / \mathrm{m}$ at $1700 \mathrm{~K}$ and 2 GPa (after Ni et al., 2011a), the addition of $10.4 \mathrm{wt} . \% \mathrm{CO}_{2}$ in the melt is responsible of an increase of the melt conductivity from $\sim 25$ to $59 \mathrm{~S} / \mathrm{m}$. Assuming, as Sifré et al. (2014) did it, that the conductivity of an hydrous carbonated basaltic melt can be further decomposed in an hydrous contribution and a carbonated one, then the dry melt with $10.4 \mathrm{wt} . \% \mathrm{CO}_{2}$ should exhibit a conductivity equal to $\sim(59-25)$ $=34 \mathrm{~S} / \mathrm{m}$, a value in agreement with the estimation of Yoshino et al. (2012) for a carbonated peridotite (10-30 S/m). So it turns out that these conductivity values are of the same order of magnitude that those obtained from FPMD for $\mathrm{CO}_{2}$-bearing melts at $2073 \mathrm{~K}$ and $\sim 12 \mathrm{GPa}$ (i.e. $\sim 31-34 \mathrm{~S} / \mathrm{m}$ ).

Actually, for a suitable comparison between simulation and experimental data we need to extrapolate the latter ones at high $\mathrm{T}$ and $\mathrm{P}$. The temperature range investigated by Sifré et al. (2014) allows extrapolating their data from 1700 to $2073 \mathrm{~K}$ with a good accuracy (see Fig.6 for an illustration). This extrapolation leads to a strong conductivity increase of the hydrous carbonated HCB-4 composition from $\sim 59 \mathrm{~S} / \mathrm{m}$ at $1700 \mathrm{~K}$ to about $\sim 293 \mathrm{~S} / \mathrm{m}$ at $2073 \mathrm{~K}$. From this latter value, the 
conductivity of the corresponding anhydrous carbonated melt can be estimated about $\sim 242 \mathrm{~S} / \mathrm{m}$ in leaving out the hydrous contribution ( $\sim 51 \mathrm{~S} / \mathrm{m}$, as evaluated from the data of $\mathrm{Ni}$ et al. (2011a)). If we apply the same kind of high-temperature extrapolation to the other hydrous carbonated basalts investigated by Sifré et al. (2014), one find that the high temperature conductivity of anhydrous carbonated melts varies little with the composition (e.g. at $2073 \mathrm{~K}$ and $3 \mathrm{GPa}, \sigma=216 \mathrm{~S} / \mathrm{m}$ for HBC7 with $\sim 16$ wt. $\% \mathrm{SiO}_{2}$ and $\sim 18$ wt. $\% \mathrm{CO}_{2}$, and $\sigma=280 \mathrm{~S} / \mathrm{m}$ for HCB-9 with $\sim 5$ wt. $\% \mathrm{SiO}_{2}$ and $\sim 23$ wt.\% $\left.\mathrm{CO}_{2}\right)$.

In summary, the conductivity data at our disposal indicate that the electrical conductivity of a basic or an ultrabasic melt at high temperature (e.g. $2073 \mathrm{~K}$ ) and moderate pressure (e.g. $3 \mathrm{GPa}$ ) increases by roughly one order of magnitude when adding 10 to $20 \mathrm{wt} \% \mathrm{CO}_{2}$ (from $10-30 \mathrm{~S} / \mathrm{m}$ in $\mathrm{CO}_{2}$-free melts to $200-300 \mathrm{~S} / \mathrm{m}$ in $\mathrm{CO}_{2}$-bearing melts), the magnitude of the conductivity being weakly dependent on composition. Clearly our simulation results do not predict this strong increase of the conductivity when adding large $\mathrm{CO}_{2}$ amounts, although the weak dependence on the melt composition is well reproduced. This discrepancy could be due to the high pressure of the simulated melts (12 GPa instead of $3 \mathrm{GPa}$ for the experimental data). Although, at our knowledge, there is no data on the role of the pressure on the electrical conductivity of $\mathrm{CO}_{2}$-bearing silicate melts, an interesting proxy is given by molten calcium carbonate $\left(\mathrm{CaCO}_{3}\right)$ which is an end member of carbonatites. A recent study (Vuilleumier et al., 2014) has shown that the properties of molten calcium carbonate are very well described by FPMD and MD simulations and especially the viscosity and the electrical conductivity which agree quantitatively with the recent data of Kono et al. (2014) and Sifré et al. (2015). Thus, the conductivity of liquid $\mathrm{CaCO}_{3}$ at $2073 \mathrm{~K}$ and $3 \mathrm{GPa}$ is about $\sim 320 \mathrm{~S} / \mathrm{m}$ (Sifré et al. (2015)), a value very similar to that exhibited by carbonated silicate melts ( $293 \mathrm{~S} / \mathrm{m}$ for the HBC-4 composition of Sifré et al. (2014), see Fig.6). At $12 \mathrm{GPa}$ and $2073 \mathrm{~K}$ the conductivity of $\mathrm{CaCO}_{3}$ is evaluated to be about $~ 90$ S/m (Vuilleumier et al., 2014), i.e. a value three to four times lower than the value at $3 \mathrm{GPa}$. Hence, it is likely that the conductivity of a $\mathrm{CO}_{2}$-rich silicate melt decreases with pressure as much as the one of molten calcium carbonate. Indeed, it is difficult to envisage a $\mathrm{CO}_{2}$-bearing silicate melt that would be more conductive than molten calcium carbonate at the same $\mathrm{T}$ and $\mathrm{P}$. 
Even if a pressure effect of this magnitude is effective on the electrical conductivity of $\mathrm{CO}_{2}$-bearing silicate melts (i.e. a drop by a factor of three or four between 3 and $12 \mathrm{GPa}$ ), the gap with our simulation results using effective charges is still substantial ( $\sim 30 \mathrm{~S} / \mathrm{m}$ by simulation as compared with an estimated value about $\sim 90 \mathrm{~S} / \mathrm{m})$. This discrepancy suggests that something is lacking in the evaluation of the conductivity of $\mathrm{CO}_{2}$-bearing silicate melts from the simulations. A way to reconcile theory with experiment would be to admit that the ionic charges strongly vary with the $\mathrm{CO}_{2}$ contents of the melt in evolving between the reduced values (e.g. $\left.\mathrm{z}_{\mathrm{O}}=-0.945 \mathrm{e}\right)$ well suited for describing $\mathrm{CO}_{2^{-}}$ free silicate melts and the formal values (e.g. $z_{O}=-2$ e) well adapted to molten salts (incidentally, the value $\mathrm{z}_{\mathrm{O}}=-1.55 \mathrm{e}$, leads to a conductivity about $\sim 90 \mathrm{~S} / \mathrm{m}$ for the $\mathrm{CO}_{2}$-bearing basaltic and kimberlitic melts). A way to circumvent this problem should be to evaluate on the fly of the FPMD simulation the contribution to the conductivity coming from the electronic polarization of the oxygens in the melt. This can be done in following, for instance, the procedure of Salanne et al. (2008), but it is costly in computer time and we delay this important task for a future study.

\section{SUMMARY}

The use of FPMD calculations has allowed us to quantify the speciation of $\mathrm{CO}_{2}$ in two $\mathrm{CO}_{2}$-rich silicate melts at high temperature and pressure. In the basaltic composition, $\mathrm{CO}_{2}$ is incorporated under the form of a minority population of $\mathrm{CO}_{2}$ molecules and a prevailing population of carbonate ions. In contrast, the amount of $\mathrm{CO}_{2}$ molecules is found to be much weaker in the kimberlitic melt. These results are somewhat different from those predicted from classical MD simulations (see also Guillot and Sator, 2011), because the effect of the melt composition on the speciation is much more marked in the FPMD calculations in going from the basaltic to the kimberlitic composition. At this stage it is worthwhile to recall that $\mathrm{CO}_{2}$ molecules are not detected in IR spectroscopy of $\mathrm{CO}_{2}$-bearing basaltic glasses because the temperature drop experienced by the quenched sample induces the transformation of $\mathrm{CO}_{2}$ molecules into carbonate ions (Morizet et al., 2001; Nowak et al., 2003; Spickenbom et al., 2010; Guillot and Sator, 2011). But it has been recently shown from synchrotron infrared spectroscopy (Konschak and Keppler, 2014) that upon heating under high compression, molecular $\mathrm{CO}_{2}$ re-appears and depolymerized melts likely contain appreciable amounts of molecular $\mathrm{CO}_{2}$ at temperatures higher 
than $\sim 1773 \mathrm{~K}$. These observations are in accordance with the present results on basaltic melt. Incidentally, the FPMD calculations have led to the identification of a transient species in the basaltic melt, the pyrocarbonate ion $\mathrm{C}_{2} \mathrm{O}_{5}{ }^{2-}$, formed in the reaction between $\mathrm{CO}_{2}$ and $\mathrm{CO}_{3}{ }^{2-}$. This dianion,

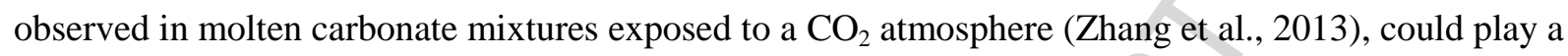
role in the valorization of $\mathrm{CO}_{2}$ in fuel cell technology using molten carbonates (Cassir et al., 2012).

With regard to the melt structure, it has been shown that the incorporation of carbonate ions into the silicate network reorganizes the latter one by transforming some of the oxygens ( $\mathrm{BO}$ and $\mathrm{NBO}$ ) of the network into bridging, non-bridging, and free carbonates. Therefore, in the basaltic melt a majority of carbonate ions are non-bridging or free, whereas in the kimberlitic melt most of them are free (i.e. they are linked to alkaline earth cations) and are not directly connected to the silicate network. This drastic evolution in the solvation structure of the carbonate ions with the melt composition may help to understand the complex behavior observed in melting relations of carbonate-silicate assemblages. As a matter of fact, our calculations suggest that $\mathrm{CO}_{2}$-rich silicate melts are composed of two intricate networks, a silicate one, which is more or less depolymerized according to the $\mathrm{SiO}_{2}$ content, and a carbonatitic one that is fully depolymerized. When the initial $\mathrm{SiO}_{2}$ content of the melt is low (e.g. a kimberlitic composition), the two sub-networks exhibit roughly the same viscosity as long as temperature and pressure are high. Hence the silicate and the carbonatitic components are expected to be miscible with each other in a large proportion, a finding which can explain the continuous change observed in the melt composition (from carbonatitic to kimberlitic) when increasing the temperature well above the solidus at a pressure exceeding $~ 3 \mathrm{GPa}$ in the $\mathrm{CMAS}-\mathrm{CO}_{2}$ system (Gudfinnsson and Presnall, 2005).

A different situation occurs at lower temperatures and pressures when the $\mathrm{SiO}_{2}$ content of the melt is basaltic-like. Then the difference in viscosity between the two sub networks increases markedly (e.g. 2. Pa.s in basalts at $1673 \mathrm{~K}$ and $2 \mathrm{GPa}$ as compared with $\sim 0.006 \mathrm{~Pa}$.s in molten $\mathrm{CaCO}_{3}$ at the same T-P conditions, see Kushiro (1986) and Kono et al. (2014)). This large difference in viscosity may trigger a spinodal decomposition leading to a miscibility gap (Cahn, 1965). For instance, in partial melting experiments of carbonated peridotite in the $\mathrm{CMAS}-\mathrm{CO}_{2}$ system near the solidus at around $2 \mathrm{GPa}$, the crystalline phase assemblage is found to be at equilibrium with two liquids (and a 
$\mathrm{CO}_{2}$ vapor) which are silicate (with a low $\mathrm{CO}_{2}$ abundance) and carbonatitic in composition (Keshav and Gunfinnsson, 2013). In the same way in melts of natural carbonated pelites a miscibility gap is observed up to $\sim 5 \mathrm{GPa}$ whereas above this pressure the carbonatite-silicate melt immiscibility vanishes rapidly (Thomsen and Schmidt, 2008; Grassi and Schmidt, 2011). Thus, a possible scenario is that at high pressures and temperatures a carbonatitic melt coming from the incipient melting of a $\mathrm{CO}_{2}$-rich source region is fully miscible with the silicate melt produced during magma ascent (because a significant proportion of the carbonate ions are dissolved as free carbonates as long as the melt is silica-undersaturated). For magma rising along a mantle adiabat, it may happen that the increasing difference in melt structure between the carbonatitic component and the silicate melt triggers spinodal decomposition leading to two liquids of very different viscosity. This liquid-liquid phase separation could play an important role in the genesis of a $\mathrm{CO}_{2}$-rich volcanism.

A surprising result of the present study is that the structural changes induced by the incorporation of a large amount of $\mathrm{CO}_{2}$ into a basaltic or kimberlitic melt have a very weak influence on the ionic diffusivities. The main reason for this behavior is likely the high temperature of investigation. A consequence of the weak dependence is that the large increase in the electrical conductivity observed in carbonated basaltic melts (Sifré et al., 2014) cannot be reproduced if the ionic charges associated with the elements of the melt are assumed to be independent of the $\mathrm{CO}_{2}$ content. The presence of carbonate ions modifies in some way the charge distribution through the network and, hence, the conductivity of the melt. The elucidation of this mechanism is an important topic for future simulation studies. Last but not least, a direct comparison between FPMD and MD simulations has shown that the empirical force field used to describe carbonated silicate melts needs to be improved in several aspects $\left(\mathrm{CO}_{2}\right.$ speciation, melt structure and ionic diffusivities). This task is currently under way.

\section{Acknowledgements}

The research leading to these results has received funding from the Agence Nationale pour la Recherche (under Grant agreement ANR-2010-BLAN-621-03), the European Community's Seventh Framework Programme (FP7/2007-2013) under Grant agreement (ERC, N²79790), and from CSCS 
(Centro Svizzero di Calcolo Scientifico, Lugano, Switzerland, project s425). FPMD calculations were performed using HPC resources from GENCI-CINES/IDRIS (Grants x2011086383 and x2012086383).

\section{Bibliography}

Ai Y. And Lange R.A. (2008) New acoustic velocity measurements on $\mathrm{CaO}-\mathrm{MgO}-\mathrm{Al}_{2} \mathrm{O}_{3}-\mathrm{SiO}_{2}$ liquids: Reevaluation of the volume and compressibility of $\mathrm{CaMgSi}_{2} \mathrm{O}_{6}-\mathrm{CaAl}_{2} \mathrm{Si}_{2} \mathrm{O}_{8}$ liquids to $25 \mathrm{GPa}$. $\mathrm{J}$. Geophys. Res. 113, B04203 1-17.

Amalberti J., Neuville D.R., Sarda Ph., Sator N., and Guillot B. (2011) Quantification of $\mathrm{CO}_{2}$ dissolved in silicate glasses and melts using Raman spectroscopy: Implications for geodynamics. Miner. Mag. 75, Goldschmidt abstracts, p.403.

Asimow P.D. and Ahrens T.J. (2010) Shock compression of liquid silicates to 125 GPa: The anorthitediopside join. J. Geophys. Res. 115, B10209 1-28.

Baba K., Chave A.D., Evans R. L., Hirth G., and Mackie R.L. (2006). Mantle dynamics beneath the East Pacific Rise at $17^{\circ} \mathrm{S}$ : insights from the Mantle Electromagnetic and Tomography (MELT) experiment. J. Geophys. Res. 111, B02101.

Baba K., Utada H., Goto T., Kasaya T., Shimizu H., and Tada N. (2010). Electrical conductivity imaging of the Philippine sea upper mantle using seafloor magnetotelluric data. Phys. Earth Planet. Int. 183, 44-62.

Bailey D.K. and Kearns S. (2012). New forms of abundant carbonate-silicate volcanism: recognition criteria and further target locations. Miner. Mag. 76, 271-284.

Bauchy M., Guillot B., Micoulaut M. and Sator N. (2012) Viscosity and viscosity anomalies of model silicates and magmas: A numerical investigation. Chem. Geol. 346, 47-56.

Beck Ph., Brommer P., Roth J. and Trebin H.-R. (2012) Influence of polarizability on metal oxide properties studied by molecular dynamics simulations. J. Phys.: condens. Matter 24, 485401-1-8. 
Becke A.D., 1988. Density-functional exchange-energy approximation with correct asymptotic behavior. Phys. Rev. A 38, 3098-3100.

Bell K. and Simonetti A. (2010). Source of parental melts to carbonatites - critical isotopic constraints. Miner. Petrol. 98, 77-89.

Benson S.W. (1960) The foundations of chemical kinetics, McGraw-Hill series in Advanced Chemistry (New York), Chapter III, 29-31.

Billinge S.J.L. and Kanatzidis M.G., 2004. Beyond crystallography: the study of disorder, nanocrystallinity and crystallographically challenged materials with pair distribution functions. Chem. Commun., 749-760.

Bourgue E. and Richet P. (2001) The effects of dissolved $\mathrm{CO}_{2}$ on the density and viscosity of silicate melts: a preliminary study. Earth Planet. Sci. Lett. 193, 57-68.

Brearley M. and Montana A. (1989) The effect of $\mathrm{CO}_{2}$ on the viscosity of silicate liquids at highpressure. Geochim. Cosmochim. Acta 53, 2609-2616.

Brooker R.A., Kohn S.C., Holloway, J.R., MCMillan P.F. and Carroll M.R. (1999) Solubility, speciation and dissolution mechanisms for $\mathrm{CO}_{2}$ in melts on the NaAL02-SiO2 join. Geochim. Cosmochim. Acta 63, 3549-3565.

Brooker R.A., Kohn S.C., Holloway, J.R. and MCMillan P.F. (2001a) Structural controls on the solubility of $\mathrm{CO}_{2}$ in silicate melts Part I: bulk solubility data. Chem. Geol. 174, 225-239.

Brooker R.A., Kohn S.C., Holloway, J.R. and MCMillan P.F. (2001b) Structural controls on the solubility of $\mathrm{CO}_{2}$ in silicate melts Part II: IR characteristics of carbonate groups in silicate glasses. Chem. Geol. 174, 241-254.

Brooker R.A., Sparks R.S.J., Kavanagh J.L. and Field M. (2011) The volatile content of hypabyssal kimberlite magmas: some constraints from experiments on natural rock compositions. Bull. Volcanol. 73, 959-981.

Bruna P.J., Grein F. and Passmore J. (2011) Density functional theory (DFT) calculations on the structures and stabilities of $\left[\mathrm{C}_{\mathrm{n}} \mathrm{O}_{2 \mathrm{n}+1}\right]^{2-}$ and $\left[\mathrm{C}_{\mathrm{n}} \mathrm{O}_{2 \mathrm{n}+1}\right] \mathrm{X}_{2}$ polycarbonates containing chainlike $\left(\mathrm{CO}_{2}\right) \mathrm{n}$ units ( $\mathrm{n}=2-6 ; \mathrm{X}=\mathrm{H}$ or Li). Can. J. Chem. 89, 671-687. 
Cahn J.W. (1965) Phase separation by spinodal decomposition in isotropic systems. J. Chem. Phys. 42, 93-99.

Canil D. and Scarfe C.M. (1990) Phase relations in peridotite $+\mathrm{CO}_{2}$ systems to $12 \mathrm{GPa}$ : implications for the origin of kimberlite and carbonate stability in the Earth's upper mantle. J. Geophys Res. 95, 15805-15816.

Carré A., Horbach J., Ispas S. and Kob W. (2008) New fitting scheme to obtain effective potential from Car-Parrinello molecular-dynamics simulations: Application to silica. Eur. Phys. Lett. 82, 17001$1-6$.

Cassir M., McPhail S.J. and Moreno A. (2012) Strategies and new developments in the field of molten carbonates and high-temperature fuel cells in the carbon cycle. Int. J. Hydrogen Energy 24, 1934519350.

Claes P., Moyaux D. and Peeters D. (1999a) Solubility and salvation of carbon dioxide in the molten $\mathrm{Li}_{2} \mathrm{CO}_{3} / \mathrm{Na}_{2} \mathrm{CO}_{3} / \mathrm{K}_{2} \mathrm{CO}_{3}$ (43.5:31.5:25.0 mol\%) eutectic mixture at $973 \mathrm{~K} \mathrm{I}$. Experimental part. Eur. J. Inorg. Chem., 589-592.

Courtial P. and Dingwell D.B. (1999) Densities of melts in the $\mathrm{CaO}-\mathrm{MgO}-\mathrm{Al}_{2} \mathrm{O}_{3}-\mathrm{SiO}_{2}$ system. Am. Mineral. 84, 465-476.

Dalton J.A. and Presnall D.C. (1998) The continuum of primary carbonatitic-kimberlitic melt compositions in equilibrium with lherzolite: Data from the system $\mathrm{CaO}-\mathrm{MgO}-\mathrm{Al}_{2} \mathrm{O}_{3}-\mathrm{SiO}_{2}-\mathrm{CO}_{2}$ at 6 GPa. J. Petrol. 39, 1953-1964.

Dasgupta R. and Hirschmann M.M. (2007) Melting in the Earth's deep upper mantle caused by carbon dioxide. Nature 440, 659-662.

Dasgupta R., Mallik A., Tsuno K., Withers A.C., Hirth G., and Hirschmann M.M. (2013). Carbondioxide-rich silicate melt in the Earth's upper mantle. Nature 493, 211-215.

Duncan M.S. and Agee C.B. (2011) The partial molr volume of carbon dioxide in peridotite partial melt at high pressure. Earth Planet. Sci. Lett. 312, 429-436. 
Eggler D.H. (1976) Does $\mathrm{CO}_{2}$ cause partial melting in the low-velocity layer of the mantle ? Geology 4, 69-72.

Ernst R.E. and Bell K. (2010). Large igneous provinces (LIPs) and carbonatites. Miner. Petrol. 98, 5576.

Eyring H. (1936) Viscosity, plasticity, and diffusion as examples of absolute reaction rates. J. Chem. Phys. 4, 283-291.

Fine G. and Stolper E. (1985) The speciation of carbon dioxide in sodium aluminosilicate glasses. Contrib. Mineral. Petrol. 91, 105-121.

Fine G. and Stolper E. (1985/1986) Dissolved carbon dioxide in basaltic glasses: concentrations and speciation. Earth Planet. Sci. Lett. 76, 263-278.

Fogel R.A. and Rutherford M.J. (1990) The solubility of carbon dioxide in rhyolitic melts: A quantitative FTIR study. Am. Mineral. 75, 1311-1326.

Gaillard F., Malki M., Iacono-Marziano G., Pichavant M., and Scaillet B. (2008). Small amount of carbonatite melts explains high electrical conductivity in the astenosphere. Science 322, 1363-1365.

Ghosh S., Ohtani E., Litasov K., Suzuki A. and Sakamaki T. (2007) Stability of carbonated magmas at the base of the Earth's upper mantle. Geophys. Lett. 34, 22312-1-5.

Goedecker S., Teter M., and Hutter J. (1996). Separable dual-space gaussian pseudopotentials. Physical Review B 54, 1703-1710.

Grandjean A., Malki M., Simmonet C., Manara D. and Penelon B. (2007) Correlation between electrical conductivity, viscosity, and structure in bororsilicate glass-forming melts. Phys. Rev. B 75, 054112-1-7.

Grassi D. and Schmidt M.W. (2011) The melting of carbonated pelites from 70 to $700 \mathrm{~km}$ depth. J. Petrol. 52, 765-789.

Grimme S. (2006). Semiempirical GGA-type density functional constructed with a long-range dispersion correction. J. Comput. Chem. 27, 1787-1799. 
Gudfinnsson G. and Presnall D.C. (2005) Continuous gradations among primary carbonatitic, kimberlitic, melilititic, basaltic, picritic, and komatiitic melts in equilibrium with garnet lherzolite at 38 GPa. J. Petrol. 46, 1645-1659.

Guillot B. and Sator N. (2007a) A computer simulation study of natural silicate melts. Part I: Low pressure properties. Geochim. Cosmochim. Acta 71, 1249-1265.

Guillot B. and Sator N. (2007b) A computer simulation study of natural silicate melts. Part II: High pressure properties. Geochim. Cosmochim. Acta 71, 4538-4556.

Guillot B. and Sator N. (2011). Carbon dioxide in silicate melts: A molecular dynamics simulation study, GCA 75, 1829-1857.

Harris K.R. (2010). Relations between the fractional Stokes-Einstein and Nernst-Einstein equations and velocity correlation coefficients in ionic liquids and molten salts. J. Phys. Chem. B 114, 95729577.

Hartwigsen C., Goedecker S., and Hutter J. (1998). Relativistic separable dual-space gaussian pseudopotentials from H to Rn. Physical Review B 58, 3641-3662.

Hékinian R., Pineau F., Shilobreeva S., Bideau D., Garcia E. and Javoy M (2000) Deep sea activity on the Mid-Atlantic Ridge near $34^{\circ} 50^{\prime} \mathrm{N}$ : Magma composition, vesicularity and volatile content. J. Volcanol. Geotherm. Res. 98, 49-77.

Helo et al. (2011) Explosive eruptions at mid-ocean ridges driven by $\mathrm{CO}_{2}$-rich magmas. Nature Geoscience 4, 260-263.

Hess B. (2002). Determining the shear viscosity of model liquids from molecular dynamics simulations. J. Chem. Phys. 116, 209-217.

Humphreys E.R., Bailey K., Hawkesworth C.J., Wall F., Najorka J., and Rankin A.H. (2012). Aragonite in olivine from Calatrava, Spain - Evidence for mantle carbonatite melts from $>100 \mathrm{~km}$ depth. Geology 38, 911-914.

Keshav S. and Gudfinnsson G.H. (2010) Experimentally dictated stability of carbonated oceanic crust to moderately great depths in the Earth: Results from the solidus determination in the system $\mathrm{CaO}-$ $\mathrm{MgO}-\mathrm{Al}_{2} \mathrm{O}_{3}-\mathrm{SiO}_{2}$. J. Geophys. Res. 115, B05205 1-20. 
Keshav S. and Gudfinnsson G.H. (2013) Silicate liquid-carbonatite liquid transition along the melting curve of model, vapor-saturated peridotite in the system $\mathrm{CaO}-\mathrm{MgO}-\mathrm{Al}_{2} \mathrm{O}_{3}-\mathrm{SiO}_{2}-\mathrm{CO}_{2}$ from 1.1 to 2 GPa. J. Geophys. Res.: Solid Earth 118, 3341-3353.

Keshav S., Gudfinnsson G.H., and Presnall D.C. (2011). Melting phase relations of simplified carbonated peridotite at $12-26 \mathrm{GPa}$ in the systems $\mathrm{CaO}-\mathrm{MgO}-\mathrm{SiO}_{2}-\mathrm{CO}_{2}$ and $\mathrm{CaO}-\mathrm{MgO}-\mathrm{Al}_{2} \mathrm{O}_{3}-\mathrm{SiO}_{2}-$ $\mathrm{CO}_{2}$ : Highly calcic magmas in the transition zone of the Earth. J. Petrol. 52, 2265-2291.

Kono Y., Kenney-Benson C., Hummer D., Ohfuji H., Park C., Shen G., Wang Y., Kavner A. and Manning C.E. (2014) Ultralow viscosity of carbonate melts at high pressures. Nature communications 6091.

Konschak A. and Keppler H. (2014) The speciation of carbon dioxide in silicate melts. Contrib. Mineral. Petrol. 167, 998.

Krack M. (2005). Pseudopotentials for $\mathrm{H}$ to $\mathrm{Kr}$ optimized for gradient-corrected exchange- correlation functionals. Theor. Chem. Acc. 114, 145-152.

Kubo R. (1966) The fluctuation-dissipation theorem. Rep. Prog. Phys. 29, 255-284.

Kushiro I. (1986) Viscosity of partial melts in the upper mantle. J. Geophys. Res. 91 (B9), 9343-9350.

LaTourrette T., Wasserburg G.J. and Fahey A.J. (1996). Self diffusion of Mg, Ca, Ba, Nd, Yb, Ti, Zr, and $\mathrm{U}$ in haplobasaltic melt. Geochim. Cosmochim. Acta 60, 1329-1340.

Lee C., Yang W., and Parr R.G. (1988). Development of the Colle-Salvetti correlation energy formula into a functional of the electron density. Phys. Rev. B 37, 785-789.

Lesher C.E., Hervig R.L. and Tinker D. (1996) Self diffusion of network formers (silicon and oxygen) in naturally occurring basaltic liquid. Geochim. Cosmochim. Acta 60, 405-413.

Liebske C., Schmickler B., Terasaki H., Poe B.T., Suzuki A., Funakoshi K.-I., Ando R. and Rubie D.C. (2005) Viscosity of peridotite liquid up to $13 \mathrm{GPa}$ : Implications for magma ocean viscosities. Earth Planet. Sci. Lett. 240, 589-604. 
Lippert G., Hutter J. and Parrinello M. (1997). A hybrid gaussian and plane wave density functional scheme. Mol. Phys. 92, 477-487.

Lizarralde D., Chave A., Hirth G., and Schultz A. (1995). Northeastern Pacific mantle conductivity profile from long-period magnetotelluric sounding using Hawaii-to-California submarine cable data. J. Geophys. Res. 100 (B9), 17837-17854.

Morizet Y., Kohn S.C. and Brooker R. (2001) Annealing experiments on $\mathrm{CO}_{2}$-bearing jadeite glass: an insight into the true temperature dependence of $\mathrm{CO}_{2}$ speciation in silicate melt. Mineral. Mag. 65, 701707.

Morizet Y., Brooker R.A. and Kohn S.C. (2002) $\mathrm{CO}_{2}$ in haplo-phonolite melt: Solubility, speciation and carbonate complexation. Geochim. Cosmochim. Acta 66, 1809-1820.

Morizet Y., Nichols A.R.L., Kohn S.C., Brooker R.A., and D. Dingwell (2007). The influence of $\mathrm{H}_{2} \mathrm{O}$ and $\mathrm{CO}_{2}$ on the glass transition temperature: insights into the effects of volatiles on magma viscosity. Eur. J. Mineral. 19, 657-669.

Mueller H.J., Stroncik N., Naumann R., Lathe C., Spiwek M., Wehber M., Schilling F.R. and Lauterjung J. (2010) High-pressure falling sphere viscosimetry of basaltic and dacitic rocks in conjunction with synchrotron radiation. J. Phys.: Conf. series 215, 012028-1-11.

Mysen B. (1975) The role of volatiles in silicate melts: Solubility of carbon dioxide and water in feldspar, pyroxene, and feldspathoid melts to $30 \mathrm{~kb}$ and $1625^{\circ} \mathrm{C}$. Am. J. Sci. 276, 969-996.

Mysen, B.O. and Richet P., 2005. Silicate Glasses and Melts: Properties and Structure. Elsevier, Amsterdam.

Ni H., Keppler H. and Behrens H. (2011a) Electrical conductivity of hydrous basaltic melts: implications for partial melting in the upper mantle. Contrib. Mineral. Petrol. 162, 637-650.

Ni H., Keppler H., Manthilake M.A.G.M. and Katsura T. (2011b) Electrical conductivity of dry and hydrous $\mathrm{NaAlSi}_{3} \mathrm{O}_{8}$ glasses and liquids at high pressures. Contrib. Mineral. Petrol. 162, 501-513.

Nosé, S. (1984a). A molecular-dynamics method for simulations in the canonical ensemble. Mol.

Phys. 52, 255-268. 
Nosé, S. (1984b). A unified formulation of the constant temperature molecular-dynamics methods. J.

Chem. Phys. 81, 511-519.

Nowak M., Porbatzki D., Spickenbom and Diedrich O. (2003) Carbon dioxide speciation in silicate melts: a restart. Earth Planet. Sci. Lett. 207, 131-139.

Nowak M., Schreen D. and Spickenbom K. (2004) Argon and $\mathrm{CO}_{2}$ on the race track in silicate melts: A tool for the development of a $\mathrm{CO}_{2}$ speciation and diffusion model. Geochim. Cosmochim. Acta 68 , $5127-5138$.

O’Dwyer Brown L., Lesher C.E., Terasaki H.G.,Yamada A., Sakamaki T., Shibazaki Y. and Ohtani E. (2009) Pressure dependence of komatiite liquid viscosity and implications for magma ocean rheology. AGU fall meeting abstract \#MR31C-07.

Pan V., Holloway J.R. and Hervig R.L. (1991) The pressure and temperature dependence of carbon dioxide solubility in tholeiitic basalt melts. Geochim. Cosmochim. Acta 55, 1587-1595.

Peeters D., Moyaux D. and Claes P. (1999b) Solubility and salvation of carbon dioxide in the molten $\mathrm{Li}_{2} \mathrm{CO}_{3} / \mathrm{Na}_{2} \mathrm{CO}_{3} / \mathrm{K}_{2} \mathrm{CO}_{3}$ (43.5:31.5:25.0 mol\%) eutectic mixture at $973 \mathrm{~K}$ II. Theoretical part. Eur. J. Inorg. Chem., 589-592.

Pineau F., Shilobreeva S., Hékinian, Bideau D. and Javoy M (2004) Deep sea activity on the MidAtlantic Ridge near $34^{\circ} 50^{\prime} \mathrm{N}$ : a stable isotope (C, H, O) study. Chem. Geol. 211, 159-175.

Pommier A. (2014) Interpretation of magnetotelluric results using laboratory measurements. Surv. Geophys. 35, 41-84.

Pommier A., Evans R.L., Key K., Tyburczy J.A., Mackwell S. and Elsebek J. (2013) Prediction of silicate melt viscosity from electrical conductivity: A model and its geophysical implications. Geochem. Geophys. Geosyst. 14, 1685-1692.

Rai C.S. and Manghnani M.H. (1978) Electrical conductivity of ultramafic rocks to 1820 Kelvin. Phys. Earth Planet. Int. 17, 6-13.

Reid J.E., Poe B.T., Rubie D.C., Zotov N. and Wiedenbeck M. (2001) The self-diffusion of silicon and oxygen in diopside $\left(\mathrm{CaMg}_{2} \mathrm{SiO}_{6}\right)$ liquid up to $15 \mathrm{GPa}$. Chem. Geol. 174, 77-86. 
Reid J.E., Suzuki A., Funakoshi K.-I., Terasaki H., Poe B.T., Rubie D.C. and Ohtani E. (2003) The viscosity of $\mathrm{CaMgSi}_{2} \mathrm{O}_{6}$ liquid at pressures up to $13 \mathrm{GPa}$. Phys. Earth Planet. Int. 139, 45-54.

Rigden S.M., Ahrens T.J., and Stolper E.M. (1988) Shok compression of molten silicate: Results for a model basaltic composition. J. Geophys. Res. 93, 367-382.

Rivers M.L. and Carmichael I.S.E. (1987) Ultrasonic studies of silicate melts. J. Geophys. Res. 92 (B9), 9247-9270.

Russell, Porritt L.A., Lavallée Y. and Dingwell D.B. (2012) Kimberlite ascent by assimilation-fuelled buoyancy. Nature 481, 352-356.

Sakamaki T., Ohtani E., Urakawa S., Suzuki A. and Katayama Y. (2010). Density of dry peridotite magma at high pressure using an X-ray absorption method. Am. Mineral. 95, 144-147.

Sakamaki T., Ohtani E., Urakawa S., Terasaki H. and Katayama Y. (2010). Density of carbonated peridotite magma at high pressure using an X-ray absorption method. Am. Mineral. 96, 553-557.

Salanne M., Vuilleumier R., Madden P.A., Simon C., Turq P. and Guillot B. (2008) Polarizabilities of individual molecules and ions in liquids from first-principles. J. Phys. Condens. Matter 20, 494207-18 .

Scarfe C.M., Cronin D.J., Wenzel J.T. and Kauffman D.A. (1983) Viscosity-temperature relationships at $1 \mathrm{~atm}$ in the system diopside-anorthite. Am. Mineral. 68, 1083-1088.

Seifert R., Malfait W.J., Lerch P. and Sanchez-Valle (2013) Partial molar volume and compressibility of dissolved CO2 in glasses with magmatic compositions. Chem. Geol. 358, 119-130.

Shaw C.S.J. (2004) Mechanisms and rates of quartz dissolution in melts in the CMAS (CaO-MgO$\mathrm{Al}_{2} \mathrm{O}_{3}-\mathrm{SiO}_{2}$ ) system. Contrib. Mineral. Petrol. 148, 180-200.

Sifré D., Gardés E., Massuyeau M., Hashim L., Hier-Majunder S. and F. Gaillard (2014) Electrical conductivity during incipient melting in the oceanic low-velocity zone. Nature 509, 81-85.

Sifré D., Hashim L. and Gaillard F. (2015) Effects of temperature, pressure and chemical compositions on theelectrical conductivity of carbonated melts and its relationship with viscosity. Chem. Geol., this issue. 
Smith W. and Forester T. (1996). DL_Poly_2.0: a general-purpose parallel molecular dynamics simulation package. J. Mol. Graph. 14, 136-141.

Sohn R.A., Willis C., Humphris S., Shank T.M., Singh H., Edmonds H.N., Kunz K., Hedman U., Helmkr E., Jakuba M., Liljebladh B., Linder J., Murphy C., Nakamura K.-I, Sato T., Schlindwein V., Stranne C., Tausenfreund M., Upchurch L., Winsor P., Jakobsson M and Soule A.(2008) Explosive volcanism on the ultralow-spreading Gakkel ridge, Arctic Ocean. Nature 453, 1236-1238.

Sparks R.S.J., Baker L., Brown R.J., Field M., Schumacher J., Stripp G. ans Walters A. (2006) Dynamical constraints on kimberlite volcanism. J. Volcanol. Geotherm. Res. 155, 18-48.

Spice H., Sanloup C., Cochain B., de Grouchy Ch. And Kono Y. (2014) Viscosity of liquid fayalite up to $9 \mathrm{GPa}$. Geochim. Cosmochim. Acta 146, in press.

Spickenbom K., Sierralta M. and Nowak M. (2010) Carbon dioxide and argon diffusion in silicate melts: Insights into the $\mathrm{CO}_{2}$ speciation in magmas. Geochim. Cosmochim. Acta 74, 6541-6564

Stolper E., Fine G., Johnson T. and Newman S. (1987) Solubility of carbon dioxide in albitic melt. Am. Mineral. 72, 1071-1085.

Suzuki A., Ohtani E., Terasaki H. and Funakoshi K.-I. (2005) Viscosity of silicate melts in $\mathrm{CaMgSi}_{2} \mathrm{O}_{6}-\mathrm{NaAlSi}_{2} \mathrm{O}_{6}$ system at high pressure. Phys. Chem. Minerals 32, 140-145.

Thomsen T.B. and Schmidt M.W. (2008) Melting of carbonated pelites at 2.5-5.0 GPa, silicatecarbonatite liquid immiscibility, and potassium-carbon metasomatism of the mantle. Earth Planet Sci. Lett. 267, 17-31.

Tinker D., Lesher C.E. and Hutcheon I.D. (2003) Self-diffusion of Si and O in diopside-anorthite melt at high pressures. Geochim. Cosmochim. Acta 67, 133-142.

Tsuneyuki S., Tsukada M., Aoki H. and Matsui M. (1988). First principles interatomic potential of silica applied to molecular dynamics. Phys. Rev. Lett. 61, 869-872.

Tyburczy J.A. and Waff H.S. (1983) Electrical conductivity of molten basalt and andesite to 25 kilobars pressure: Geophysical significance and implications for charge transport and melt structure. J. Geophys. Res. 88, 2413-2430. 
Van Beest B.W.H., Kramer G.J. and Van Santen R.A. (1990). Force fields for silicas and aluminophosphates based on ab initio calculations. Phys. Rev. Lett. 64, 1955-1958.

VandeVondele J., Krack M., Mohamed F., Parrinello M., Chassaing T., and Hutter J. (2005a). Quickstep: Fast and accurate density functional calculations using a mixed gaussian and plane waves approach. Comput. Phys. Comm. 167, 103-128.

VandeVondele J., Mohamed F., Krack M., Hutter J., Sprik M., and Parrinello, M. (2005b). The influence of temperature and density functional models in ab initio molecular dynamics simulation of liquid water. J. Chem. Phys. 122, 014515.

VandeVondele J. and Hutter J. (2007). Gaussian basis sets for accurate calculations on molecular systems in gas and condensed phases. J. Chem. Phys. 127, 114105.

Vuilleumier R., Sator N. and Guillot B. (2009) Computer modeling of natural silicate melts: What can we learn from ab initio simulations. Geochim. Cosmochim. Acta 73, 6313-6339.

Vuilleumier R., Seitsonen A., Sator N. and Guillot B. (2014) Structure, equation of state and transport properties of molten calcium carbonate $\left(\mathrm{CaCO}_{3}\right)$ by atomistic simulations. Geochim. Cosmochim. Acta. 141, 547-566.

Waff H.S. and Weill D.F. (1975) Electrical conductivity of magmatic liquids: Effects of temperature, oxygen fugacity, and composition. Earth Planet Sci. Lett. 28, 254-260.

Walter M.J., Bulanova G.P., Armstrong L.S., Keshav S., Blundy J.D., Gudfinnsson G., Lord O.T., Lennie A.R., Clark S.M., Smith C.B., and Gobbo L. (2008). Primary carbonatite melt from deeply subducted oceanic crust. Nature 454, 622-626.

White B.S. and Montana A. (1990). The effect of $\mathrm{H}_{2} \mathrm{O}$ and $\mathrm{CO}_{2}$ on the viscosity of sanidine liquid at high-pressures. J. Geophys. Res. B 95, 15683-15693.

Woolley A.R. and Bailey D.K. (2012). The crucial role of lithospheric structure in the generation and release of carbonatites: geological evidence. Miner. Mag. 76, 259-270.

Woolley A.R. and Church A.A. (2005). Extrusive carbonatites: A brief review. Lithos 85, 1-14. 
Woolley A.R. and Kjarsgaard B.A. (2008). Paragenetic types of carbonatite as indicated by the diversity and relative abundances of associated silicate rocks: Evidence from a global database. Can. Mineral. 46, 741-752.

Wyllie P.J. and Huang W.L. (1975) Peridotite, kimberlite and carbonatite explained in the system $\mathrm{CaO}-\mathrm{MgO}-\mathrm{SiO}_{2}-\mathrm{CO}_{2}$. Geology 3, 621-624.

Yoshino T., McIsaac E., Laumonier M., and Katsura T. (2012). Electrical conductivity of partial molten carbonate peridotite. Phys. Earth Planet. Int. 194-195, 1-9.

Zhang L., Huang X., Qin C., Brinkman K., Gong Y., Wang S. and Huang K. (2013) First spectroscopic identification of pyrocarbonate for high $\mathrm{CO} 2$ flux membranes containing highly interconnected three dimensional ionic channels. Phys. Chem. Chem. Phys. 15, 13147-13152. 


\section{Table 1}

Chemical composition (in wt.\%) of the simulated melts (with and without $\mathrm{CO}_{2}$ ). The number of atoms of each species used in the simulations is also indicated.

$\begin{array}{lcrrc} & \text { Basalt }+\mathrm{CO}_{2} & \text { Basalt } & \text { Kimberlite }+\mathrm{CO}_{2} & \text { Kimberlite } \\ \mathrm{SiO}_{2} & 39.3 & 49.1 & 28.5 & 35.8 \\ \mathrm{Al}_{2} \mathrm{O}_{3} & 13.9 & 17.4 & 2.2 & 2.8 \\ \mathrm{MgO} & 13.8 & 17.3 & 29.0 & 36.6 \\ \mathrm{CaO} & 13.0 & 16.2 & 19.7 & 24.8 \\ \mathrm{CO}_{2} & 20.0 & & 20.6 & \\ N_{\mathrm{Si}} & 81 & 81 & 60 & 60 \\ N_{\mathrm{Al}} & 34 & 34 & 6 & 6 \\ N_{\mathrm{Mg}} & 43 & 43 & 90 & 90 \\ N_{\mathrm{Ca}} & 29 & 29 & 44 & 44 \\ N_{O} & 397 & 285 & 381 & 263 \\ N_{c} & 56 & & 59 & \\ \left(N_{T o t}\right) & (640) & (472) & (640) & (463)\end{array}$


Table 2

Simulation run conditions and results. The temperature $\mathrm{T}(\mathrm{K})$ and the density $n\left(\mathrm{~g} / \mathrm{cm}^{3}\right)$ are imposed during the simulation runs (NVT) and the pressure $P(\mathrm{GPa})$ is the calculated quantity. The partial molar volume of $\mathrm{CO}_{2}\left(\overline{\mathrm{V}}_{\mathrm{CO}_{2}}\right)$ is simply evaluated from the density difference between $\mathrm{CO}_{2}$-bearing and $\mathrm{CO}_{2}$-free melts at the same temperature and pressure. Notice that the value of $\overline{\mathrm{V}}_{\mathrm{CO}_{2}}$ is the same in the two calculations (FPMD versus MD) but the pressure is not.

\begin{tabular}{|c|c|c|c|c|c|c|}
\hline System & method & $\begin{array}{l}\mathrm{T} \\
(\mathrm{K})\end{array}$ & $\begin{array}{c}n \\
\left(\mathrm{~g} / \mathrm{cm}^{3}\right)\end{array}$ & $\frac{N_{\mathrm{CO}_{2}}}{N_{\mathrm{CO}_{2}}+N_{\mathrm{CO}_{3}}}$ & $\begin{array}{c}P \\
(\mathrm{GPa})\end{array}$ & $\begin{array}{c}\overline{\mathrm{V}}_{\mathrm{CO}_{2}} \\
\left(\mathrm{~cm}^{3} / \mathrm{mol}\right)\end{array}$ \\
\hline Basalt $+\mathrm{CO}_{2}$ & $\begin{array}{l}\text { FPMD } \\
\text { MD } \\
\text { (Exp) }\end{array}$ & $\begin{array}{l}2073 \\
2073\end{array}$ & $\begin{array}{l}3.04 \\
3.04\end{array}$ & $\begin{array}{c}0.15 \pm 0.08 \\
0.23 \pm 0.08\end{array}$ & $\begin{array}{l}12 \pm 2 \\
7.8 \pm 0.3\end{array}$ & $\begin{array}{l}17.7 \\
17.7 \\
\left(21^{\mathrm{a}}, 22.8^{\mathrm{b}}\right)\end{array}$ \\
\hline Basalt & $\begin{array}{l}\text { FPMD } \\
\text { MD } \\
\text { (Exp) }\end{array}$ & $\begin{array}{c}2073 \\
2073 \\
(2073)\end{array}$ & $\begin{array}{l}3.22 \\
3.22 \\
(3.22)\end{array}$ & & $\begin{array}{c}11 \pm 2 \\
7.9 \pm 0.3 \\
\left(8.3^{\mathrm{c}}, 8.8^{\mathrm{d}}\right)\end{array}$ & \\
\hline $\begin{array}{l}\text { Kimberlite } \\
\quad+\mathrm{CO}_{2}\end{array}$ & $\begin{array}{l}\text { FPMD } \\
\text { MD } \\
\text { (Exp) }\end{array}$ & $\begin{array}{l}2073 \\
2073\end{array}$ & & $\begin{array}{l}0.02 \pm 0.02 \\
0.18 \pm 0.08\end{array}$ & $\begin{array}{c}12 \pm 2 \\
8.1 \pm 0.3\end{array}$ & $\begin{array}{c}17.5 \\
17.5 \\
\left(22^{\mathrm{e}}, 28^{\mathrm{f}}\right)\end{array}$ \\
\hline Kimberlite & $\begin{array}{l}\text { FPMD } \\
\text { MD } \\
\text { (Exp) }\end{array}$ & $\begin{array}{l}2073 \\
2073 \\
(2073)\end{array}$ & $\begin{array}{l}3.20 \\
3.20 \\
(3.20)\end{array}$ & & $\begin{array}{l}13 \pm 2 \\
7.9 \pm 0.3 \\
\left(8.0^{\mathrm{g}}\right)\end{array}$ & \\
\hline
\end{tabular}

${ }^{\text {a }}$ Ghosh et al. (2007) in a MORB with 5 wt. $\% \mathrm{CO}_{2}$ at $19.5 \mathrm{GPa}$ and $2573 \mathrm{~K}$

${ }^{\text {b }}$ Seifert et al. (2013) in a basaltic glass at room temperature with 3.9 wt. $\% \mathrm{CO}_{2}$

${ }^{\mathrm{c}}$ Ai and Lange (2008) in $\mathrm{An}_{36}-\mathrm{Di}_{64}$ at $2073 \mathrm{~K}$ and $3.22 \mathrm{~g} / \mathrm{cm}^{3}$

${ }^{\mathrm{d}}$ Asimow and Ahrens (2010) in $\mathrm{An}_{36}-\mathrm{Di}_{64}$ at $2073 \mathrm{~K}$ and $3.22 \mathrm{~g} / \mathrm{cm}^{3}$

${ }^{\mathrm{e}}$ Duncan and Agee (2011) in a komatiite with $5.5 \mathrm{wt} . \% \mathrm{CO}_{2}$ at $5.5 \mathrm{GPa}$ and $2123 \mathrm{~K}$

${ }^{\mathrm{f}}$ Sakamaki et al. (2011) in a peridotite with $2.3 \mathrm{wt} \% \mathrm{CO}_{2}$ at $3.3 \mathrm{GPa}$ and $2050 \mathrm{~K}$

${ }^{\mathrm{g}}$ Sakamaki et al. (2010) for a dry peridotite at $2073 \mathrm{~K}$ and $3.20 \mathrm{~g} / \mathrm{cm}^{3}$ 


\section{Table 3}

Self-diffusion coefficients (in $10^{-9} \mathrm{~m}^{2} / \mathrm{s}$ ) of elements and electrical conductivity (in $\mathrm{S} / \mathrm{m}$ ) in $\mathrm{CO}_{2}$ bearing and $\mathrm{CO}_{2}$-free melts. The conductivity values indicated by $\sigma_{f v}$ are calculated with formal charges (e.g. $z_{O}=-2 e$ ) and those indicated by $\sigma_{e f f}$ are calculated with effective charges (e.g. $z_{O}=-0.945 e$ ), see text for a discussion. The run duration $\left(t_{\text {run }}\right)$ is indicated in ns. The statistical uncertainties amount to $\pm 30 \%$ with FPMD calculations and are about $\pm 10 \%$ with classical MD calculations.

System method $t_{\text {run }} \quad D_{S i} \quad D_{A l} \quad D_{M g} \quad D_{C a} \quad D_{C} \quad \sigma_{f v} \quad \sigma_{\text {eff }}$ (ns) $\quad\left(10^{-9} \mathrm{~m}^{2} / \mathrm{s}\right)\left(10^{-9} \mathrm{~m}^{2} / \mathrm{s}\right)\left(10^{-9} \mathrm{~m}^{2} / \mathrm{s}\right)\left(10^{-9} \mathrm{~m}^{2} / \mathrm{s}\right)\left(10^{-9} \mathrm{~m}^{2} / \mathrm{s}\right)(\mathrm{S} / \mathrm{m}) \quad(\mathrm{S} / \mathrm{m})$

\begin{tabular}{|c|c|c|c|c|c|c|c|c|c|}
\hline $\begin{array}{l}\text { Basalt } \\
\quad+\mathrm{CO}_{2}\end{array}$ & $\begin{array}{l}\text { FPMD } \\
\text { MD } \\
\text { (Exp) }\end{array}$ & $\begin{array}{l}0.02 \\
10 .\end{array}$ & $\begin{array}{l}0.32 \\
0.37\end{array}$ & $\begin{array}{c}0.37 \\
0.68\end{array}$ & $\begin{array}{l}0.67 \\
1.50\end{array}$ & $\begin{array}{l}0.42 \\
1.05\end{array}$ & $\begin{array}{c}0.5 \\
0.87\end{array}$ & $\begin{array}{l}140 \\
134 \\
\left(\sim 10-30^{\mathrm{a}}\right)\end{array}$ & $\begin{array}{l}31 \\
30\end{array}$ \\
\hline Basalt & $\begin{array}{l}\text { FPMD } \\
\text { MD } \\
\text { (Exp) }\end{array}$ & $\begin{array}{l}0.02 \\
10 .\end{array}$ & $\begin{array}{c}0.32 \\
0.47 \\
\left(0.19^{\mathrm{b}}\right) \\
\left(0.11^{\mathrm{c}}\right)\end{array}$ & $\begin{array}{l}0.37 \\
0.77\end{array}$ & $\begin{array}{l}0.63 \\
1.35 \\
\left(0.87^{\mathrm{d}}\right)\end{array}$ & $\begin{array}{l}0.63 \\
0.73 \\
\left(0.72^{\mathrm{d}}\right)\end{array}$ & & $\begin{array}{l}105 \\
224 \\
\left(\sim 17.5^{\mathrm{e}}\right)\end{array}$ & $\begin{array}{c}23 \\
50\end{array}$ \\
\hline $\begin{array}{l}\text { Kimberlite } \\
+\mathrm{CO}_{2}\end{array}$ & $\begin{array}{l}\text { FPMD } \\
\text { MD } \\
(\text { Exp) }\end{array}$ & $\begin{array}{l}0.02 \\
10 .\end{array}$ & $\begin{array}{l}0.47 \\
0.80\end{array}$ & $\begin{array}{l}0.75 \\
1.20\end{array}$ & $\begin{array}{l}0.73 \\
2.47\end{array}$ & $\begin{array}{l}0.53 \\
1.83\end{array}$ & $\begin{array}{l}0.6 \\
1.37\end{array}$ & $\begin{array}{c}150 \\
403 \\
\left(\sim 34^{f}\right)\end{array}$ & $\begin{array}{l}34 \\
90\end{array}$ \\
\hline Kimberlite & $\begin{array}{l}\text { FPMD } \\
\text { MD } \\
(\operatorname{Exp})\end{array}$ & $\begin{array}{l}0.02 \\
10 .\end{array}$ & $\begin{array}{c}0.37 \\
0.90 \\
\left(\sim 0.4^{\mathrm{g}}\right)\end{array}$ & $\begin{array}{l}0.50 \\
1.37\end{array}$ & $\begin{array}{c}0.53 \\
2.23\end{array}$ & $\begin{array}{l}0.42 \\
1.50\end{array}$ & & $\begin{array}{l}171 \\
493 \\
\left(\sim 30-50^{h}\right.\end{array}$ & $\begin{array}{r}38 \\
110 \\
\left.h^{\mathrm{h}}\right)\end{array}$ \\
\hline
\end{tabular}

${ }^{\mathrm{a}}$ Yoshino et al. (2012) in a carbonated basaltic liquid at $1700 \mathrm{~K}$ and $3 \mathrm{GPa}$, see text for a discussion.

${ }^{\mathrm{b}}$ Lesher et al. (1996) in a basaltic liquid at $2073 \mathrm{~K}$ and $1 \mathrm{GPa}$

${ }^{\mathrm{c}}$ Tinker et al. (2003) in $\mathrm{An}_{42} \mathrm{Di}_{58}$ at $2073 \mathrm{~K}$ and $4 \mathrm{GPa}$

${ }^{\mathrm{d}}$ LaTourette et al. (1996) in a haplobasaltic liquid at $2073 \mathrm{~K}$ and 1 bar

${ }^{\mathrm{e}} \mathrm{Ni}$ et al. (2011a) in a basaltic melt at $2073 \mathrm{~K}$ and $2 \mathrm{GPa}$

${ }^{\mathrm{f}}$ Sifré et al. (2014) in a carbonated kimberlitic melt (HCB-4 composition) at $1700 \mathrm{~K}$ and $3 \mathrm{GPa}$, see text for a discussion.

${ }^{g}$ Reid et al. (2001) in liquid diopside at $2273 \mathrm{~K}$ and 8 GPa

${ }^{\mathrm{h}}$ Rai and Manghnani (1978) for a peridotite at $1820 \mathrm{~K}$ and 1 bar 


\section{Figures}

Fig.1 Running average of the ratio, $\mathrm{R}(\mathrm{t})=\mathrm{N}_{\mathrm{CO}_{2}} /\left(\mathrm{N}_{\mathrm{CO}_{2}}+\mathrm{N}_{\mathrm{CO}_{3}^{2-}}\right)$, as function of run duration (in ps). The lower panel shows the results of the FPMD calculations and the upper panel those of the classical MD calculations. For convenience the initial state of the FPMD simulation is prepared with $\mathrm{R}(\mathrm{t}=0)=$ 0.5 whereas for $\mathrm{MD}$ the initial state is prepared with $\mathrm{R}(\mathrm{t}=0)=1$. In each panel, the wiggling black curve represents the basaltic melt and the wiggling red curve (color on line) the kimberlitic melt. In the upper panel, the insert shows the evolution of $\mathrm{R}(\mathrm{t})$ over a simulation time of 1,000 ps. Despite the large statistical fluctuations, value of $\mathrm{R}(\mathrm{t})$ is essentially stationary from $\sim 20$ to $1,000 \mathrm{ps}$. In the two panels the full curves (black or red) show the exponential decay predicted by kinetics theory for a second order reaction (see Benson, 1960). Values of the rate constants $k_{1}$ and $k_{2}$ obtained after curve fitting are the following: for basalt (FPMD: $k_{l}=30.10^{10} \mathrm{~s}^{-1}, k_{2}=3.110^{10} \mathrm{l} / \mathrm{mol} . \mathrm{s}$; MD: $k_{l}=7.10^{10} \mathrm{~s}^{-1}, k_{2}$ $=0.410^{10} \mathrm{l} / \mathrm{mol} . \mathrm{s}$ ) and for kimberlite (FPMD: $k_{l}=9.10^{10} \mathrm{~s}^{-1} ; k_{2}=5.710^{10} \mathrm{l} / \mathrm{mol} . \mathrm{s} ; \mathrm{MD}: k_{l}=4.810^{10} \mathrm{~s}^{-1}$, $\left.k_{2}=0.410^{10} 1 / \mathrm{mol} . \mathrm{s}\right)$. Factually, notice that the initial decay is faster with FPMD simulations than with MD, which suggests that chemical equilibrium is reached more rapidly with FPMD than with MD.

Fig.2 Lower panel: Distribution of the $\mathrm{C}-\mathrm{O}$ bond length in the carbonate ion $\left(\mathrm{CO}_{3}^{2-}\right)$ and in the pyrocarbonate ion $\left(\mathrm{C}_{2} \mathrm{O}_{5}^{2-}\right)$ occurring in the FPMD simulation. The full curves are for $\mathrm{CO}_{3}^{2-}$ in the basaltic melt (in black) and in the kimberlitic melt (in red, color on line), the dotted curve is for the C$\mathrm{O}$ bond length of the $\mathrm{CO}_{3}$ groups within the pyrocarbonate ion, and the dashed curve is for the $\mathrm{O}^{*} \mathrm{C}$ distance between the central oxygen and the two carbon atoms.

Upper panel: As in the lower panel but for the angular distribution of the bond angle $\mathrm{O}-\mathrm{C}-\mathrm{O}$ in $\mathrm{CO}_{3}^{2-}$ and $\mathrm{C}-\mathrm{O} *_{-} \mathrm{C}$ in $\mathrm{C}_{2} \mathrm{O}_{5}^{2-}$. The O-C-O bond angle distribution of $\mathrm{CO}_{2}$ molecules in the basaltic melt is also indicated.

Fig.3 Atom-atom pair distribution functions in $\mathrm{CO}_{2}$-bearing basaltic and kimberlitic melts (see Table 2 for PVT conditions). Full curves are obtained from FPMD calculations and dotted curves from classical MD simulations.

Fig.4 Characterization of carbonate groups in the silicate melt. For each category (free carbonates, non-bridging carbonates and bridging carbonates), the upper value is associated with the basaltic composition and the lower value with the kimberlitic composition. For sake of comparison, results obtained from classical MD simulations are also indicated (values in parentheses). In the pictures, carbon atoms are in blue (color on line), oxygen atoms in red, silicon atoms in yellow, aluminum atoms in pink, whereas for convenience, magnesium and calcium atoms are figured only as small dots (red or blue). 
Fig.5 Time evolution of the mean square displacement of the elements in $\mathrm{CO}_{2}$-bearing basalt ( $\log -\log$ representation). The full curves are obtained from the FPMD simulations and the dashed-dotted curves from the classical MD simulations. For the sake of clarity, the MD results below 2 ps are not reported. Notice that the diffusive regime is reached from $\sim 5$ ps with MD and between 5 and 10 ps with FPMD. The deviation between the two set of curves (the MD curves are shifted upwards with respect to the FPMD ones) indicates that the elements diffuse more rapidly in the classical MD simulation.

Fig.6 Comparison between electrical conductivity data on molten calcium carbonate at $2 \mathrm{GPa}$ (Sifré et al., 2015), hydrous carbonated basalt at 3GPa (HCB-4 composition in Sifré et al., 2014), dry basaltic melt at $2 \mathrm{GPa}$ (Ni et al., 2011a) and FPMD results for $\mathrm{CO}_{2}$-bearing basalt and kimberlite using effective charges (see $\sigma_{\text {eff }}$ in Table 3). The dotted curves show the temperature extrapolation of conductivity data up to $2073 \mathrm{~K}$. The full circles are for the $\mathrm{CO}_{2}$-bearing melts simulated by FPMD (basalt in black and kimberlite in red, color online) and the empty circles are for the corresponding $\mathrm{CO}_{2}$-free melts. 

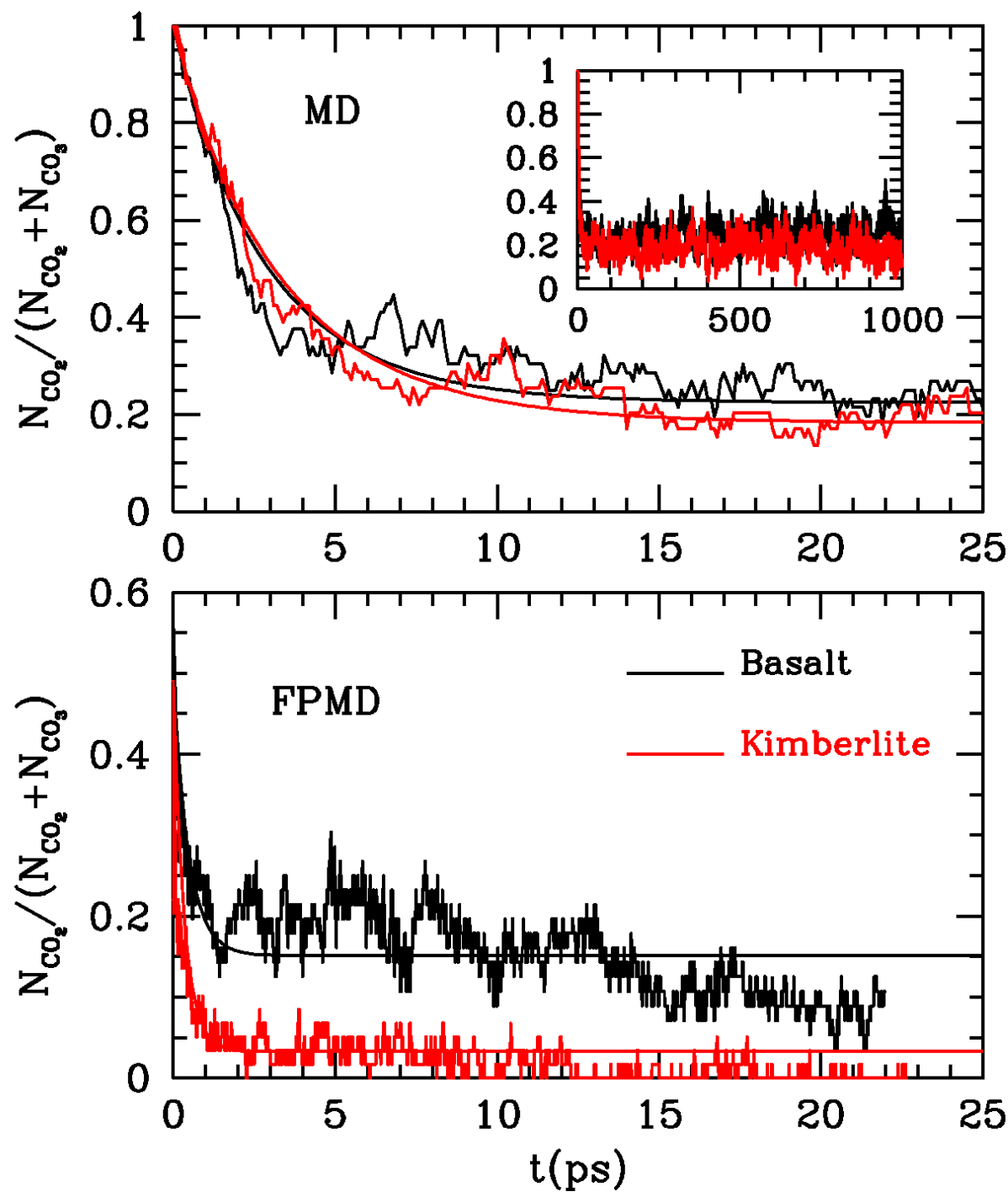

Fig.1 

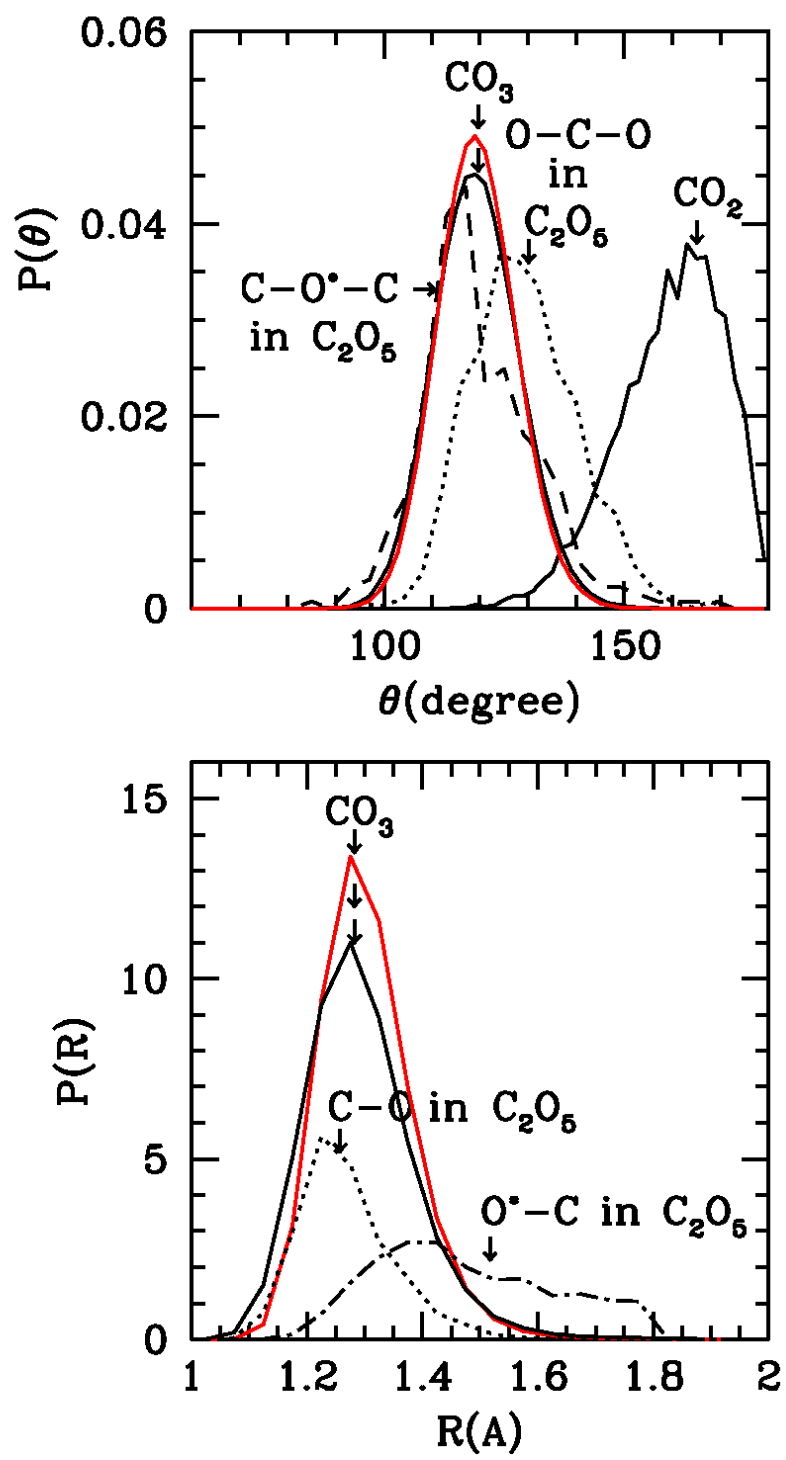

Fig.2 


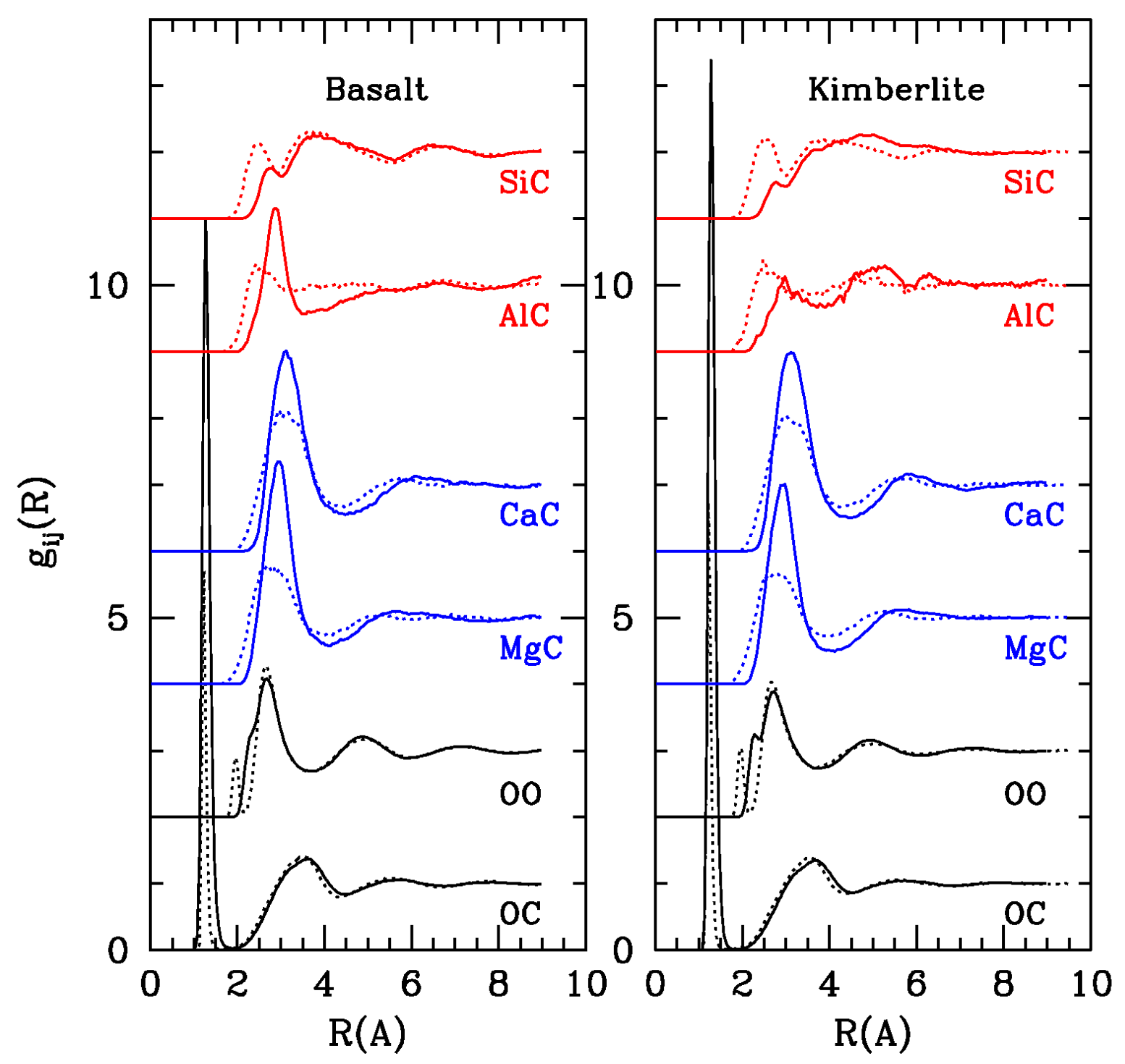

Fig.3 

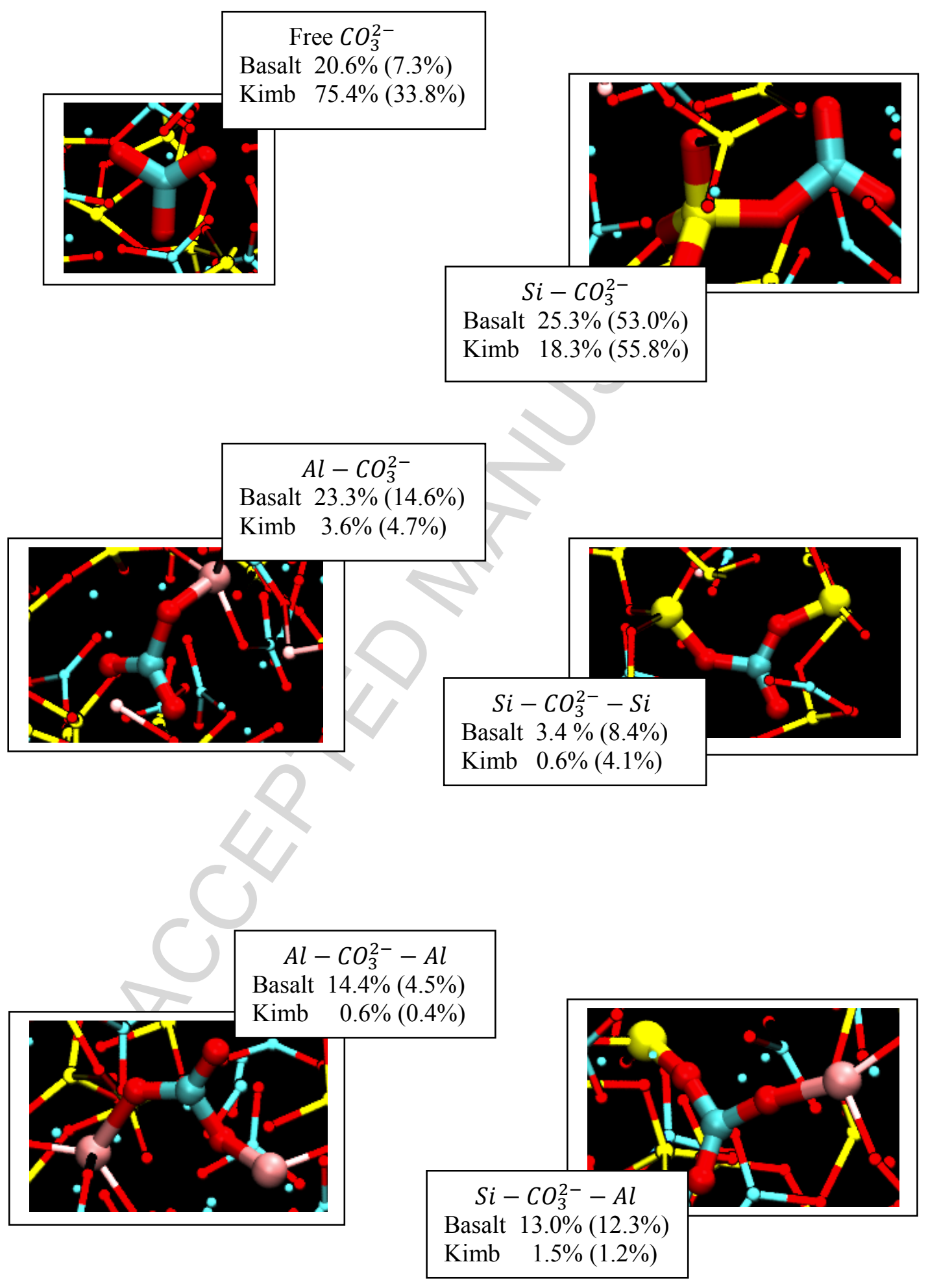

Fig.4 


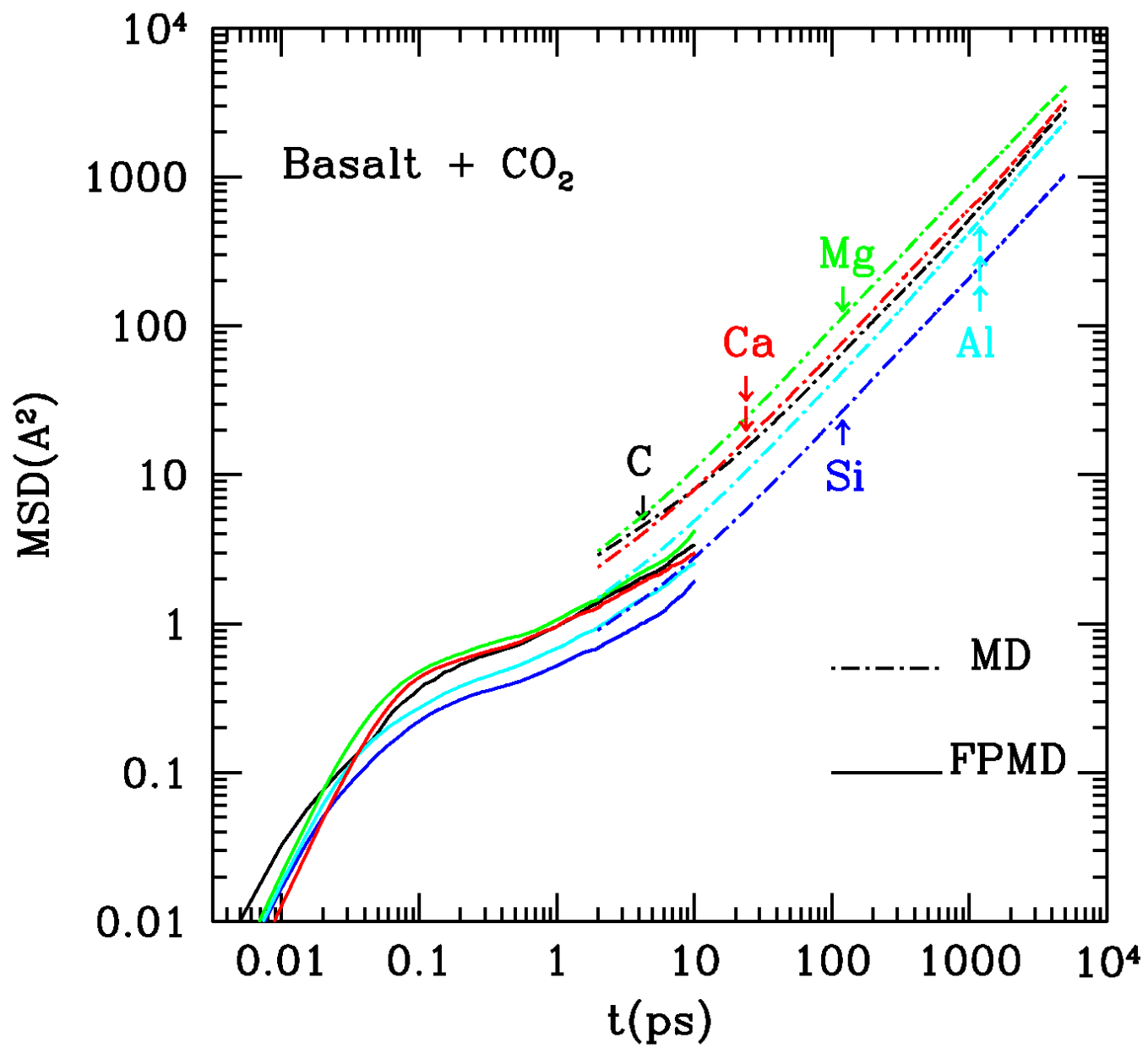

Fig.5 


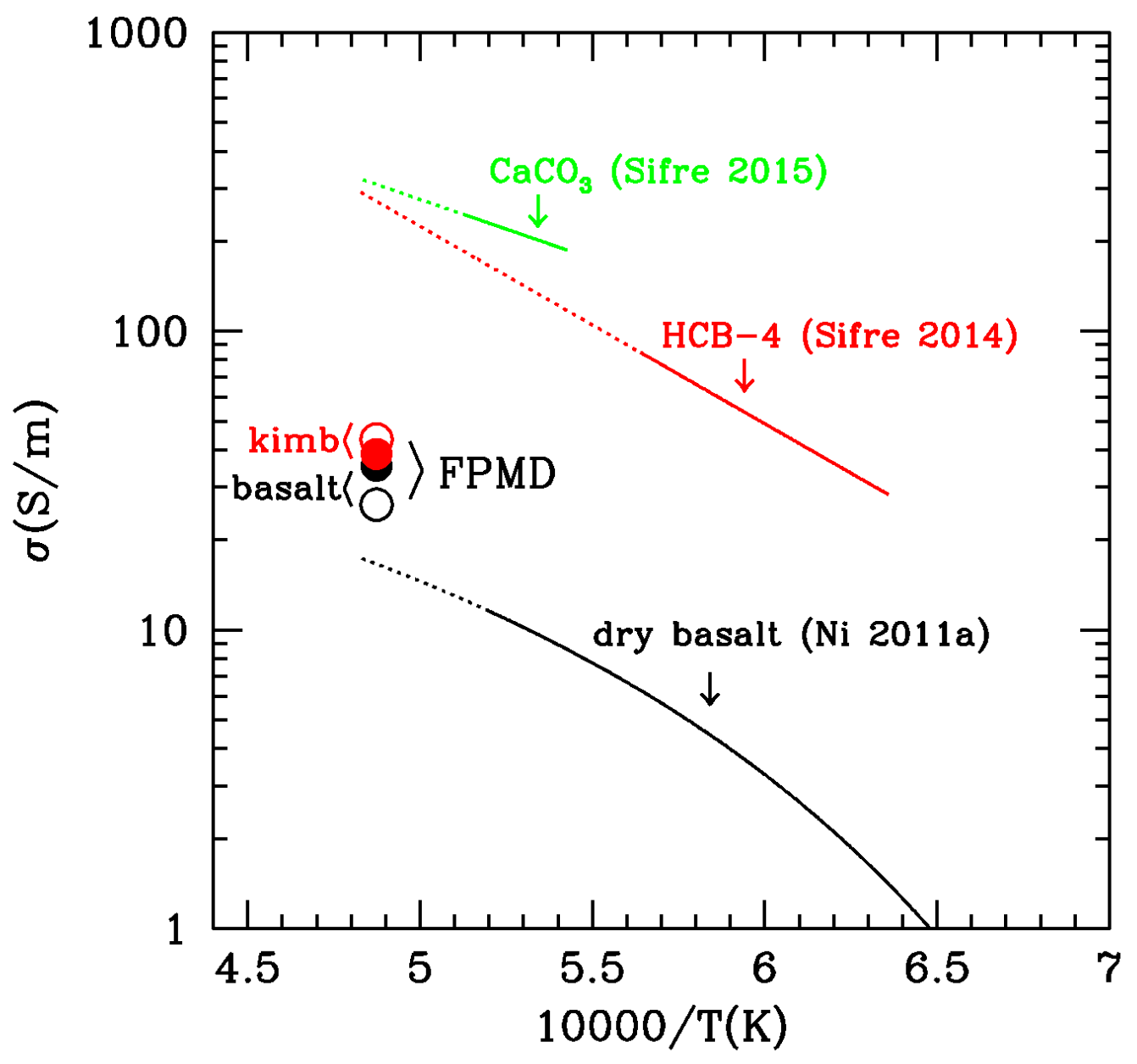

Fig.6 